\title{
On the relationship between Arctic ice clouds and polluted air masses over the North Slope of Alaska in April 2008
}

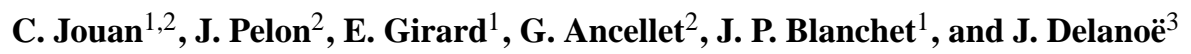 \\ ${ }^{1}$ Centre ESCER, Department of Earth and Atmospheric Sciences, University of Quebec At Montreal, H3C 3P8, Montreal, \\ Quebec, Canada \\ ${ }^{2}$ Laboratoire Atmosphère, Milieux et Observations Spatiales, UPMC, UMR8190, 75252, Paris, France \\ ${ }^{3}$ Laboratoire Atmosphère, Milieux et Observations Spatiales, UVSQ, 78035, Guyancourt, France
}

Correspondence to: C. Jouan (jouan.caroline6@gmail.com)

Received: 2 January 2013 - Published in Atmos. Chem. Phys. Discuss.: 15 February 2013

Revised: 18 October 2013 - Accepted: 29 November 2013 - Published: 3 February 2014

Abstract. Recently, two types of ice clouds (TICs) properties have been characterized using the Indirect and SemiDirect Aerosol Campaign (ISDAC) airborne measurements (Alaska, April 2008). TIC-2B were characterized by fewer $\left(<10 \mathrm{~L}^{-1}\right)$ and larger $(>110 \mu \mathrm{m})$ ice crystals, and a larger ice supersaturation (>15\%) compared to TIC-1/2A. It has been hypothesized that emissions of $\mathrm{SO}_{2}$ may reduce the ice nucleating properties of ice nuclei (IN) through acidification, resulting in a smaller concentration of larger ice crystals and leading to precipitation (e.g., cloud regime TIC2B). Here, the origin of air masses forming the ISDAC TIC1/2A (1 April 2008) and TIC-2B (15 April 2008) is investigated using trajectory tools and satellite data. Results show that the synoptic conditions favor air masses transport from three potential $\mathrm{SO}_{2}$ emission sources into Alaska: eastern China and Siberia where anthropogenic and biomass burning emissions, respectively, are produced, and the volcanic region of the Kamchatka/Aleutians. Weather conditions allow the accumulation of pollutants from eastern China and Siberia over Alaska, most probably with the contribution of acidic volcanic aerosol during the TIC-2B period. Observation Monitoring Instrument (OMI) satellite observations reveal that $\mathrm{SO}_{2}$ concentrations in air masses forming the TIC$2 \mathrm{~B}$ were larger than in air masses forming the TIC-1/2A. Airborne measurements show high acidity near the TIC-2B flight where humidity was low. These results support the hypothesis that acidic coating on IN could be at the origin of the formation of TIC-2B.

\section{Introduction}

Climate change is proceeding faster and more severely at the high latitudes of the Arctic (ACIA, 2005; IPCC, 2007). Average annual Arctic temperature has been increasing at about twice the global mean rate in the past $50 \mathrm{yr}$. The uncertainties of the amplitude and the evolution of Arctic warming are partly related to a lack of understanding of the contributions of clouds in the energy balance over this region (Dufresne and Bony, 2008). Clouds play a fundamental role both in modulating atmospheric radiation and the hydrologic cycles. This is particularly critical in the Arctic, where interactions can be enhanced by the presence of aerosols (Grenier and Blanchet, 2010; Morrison et al., 2005).

Arctic cloud properties have been investigated in a number of observational studies using aircraft, ground-based remote sensors and satellites. It was recently shown that iceonly clouds are ubiquitous in the upper troposphere during all seasons in the Arctic (Shupe, 2011; Devasthale et al., 2011). Although optically thin ice clouds may have a small effect on the radiation budget at the surface (Intrieri and Shupe, 2004; Lampert et al., 2009), their existence could be important in the Arctic spring to (1) maintain mixed phase low clouds (Morrison et al., 2005, 2012), or (2) in the winter when the warming resulting from the cloud greenhouse effect (thermal) dominates (Girard and Blanchet, 2001; Shupe and Inrieri, 2004). Cloud radiative forcing at the surface strongly depends on cloud properties, solar zenith angle, and surface albedo (Shupe and Intrieri, 2004). 
The joint detection characteristics of both CloudSat radar and the Cloud-Aerosol Lidar and Infrared Pathfinder Satellite Observations (CALIPSO) lidar recently reveal the existence of two types of ice clouds (TICs) in the Arctic during the polar night and early spring (Grenier et al., 2009; Grenier and Blanchet, 2010). The type refers to the number of active instruments detecting the cloud; ice clouds of type 1 (TIC-1) are only seen by the lidar whereas ice clouds of type 2 (TIC- 2 ) are seen by both the lidar and the radar. TIC- 2 are further divided into TIC-2A and TIC-2B. TIC-2A are topped by a substantial layer of very small (radar-unseen) ice crystals (TIC-1). In contrast, TIC-2B are not overlaided by TIC1 (Grenier et al., 2009; Grenier and Blanchet, 2010). In this paper, TIC-1 and TIC-2A are not differentiated and therefore will be identified as TIC-1/2A.

Jouan et al. (2012) have characterized the TICs microphysical and thermodynamic properties using airborne measurements taken during the Indirect and Semi-Direct Aerosol Campaign (ISDAC), which was conducted over the North Slope of Alaska (NSA) during April 2008 (McFarquhar et al., 2011). Results showed that TIC-2B are characterized by fewer $\left(<10 \mathrm{~L}^{-1}\right)$ and larger $(>110 \mu \mathrm{m})$ ice crystals and a larger ice supersaturation (by about $15 \%$ to $20 \%$ ), close to liquid water saturation at cold temperatures $\left(T_{\mathrm{a}}\right)$ below $-30^{\circ} \mathrm{C}$, when compared to TIC-1/2A. From this study, two ice clouds representing each type of TICs (TIC-1/2A and TIC-2B) observed during the ISDAC campaign were investigated in detail by Jouan et al. (2012). The synoptic analysis showed that vertical motion within these two TICs are relatively low. The analysis of cloud properties showed that most of the differences between these two TICs are located near the cloud top where the nucleation of ice crystals is most likely to occur. In the TIC-1/2A case, it was suggested that the dominant nucleation process was the deposition ice nucleation due to an atmosphere not saturated with respect to liquid water combined with a relatively high ice crystal number concentration $\left(N_{\text {ic }}\right)$. In the TIC-2B case, either immersion or condensation freezing of haze droplets (coated ice nuclei (IN)) was hypothesized due to larger relative humidity with respect to ice $\left(\mathrm{RH}_{\text {Ice }}\right)$ close to liquid water saturation.

Knowledge of the chemical composition and number concentration of the ambient ice-forming aerosol particles is important in order to understand the physical process of TICs formation. Numerous studies have attempted to quantify the ice nucleation ability of different particles empirically in laboratory experiments. Hoose and Möhler (2012) noticed that the observations of ice nucleation on a good ice nuclei such as mineral dust span the full range of water-subsaturated and water-saturated conditions below $-10^{\circ} \mathrm{C}$. However, most studies have shown that mineral dust particles are "deactivated" when they are coated with various species such as ammonium sulphate, ammonium bi-sulphate, sulfuric acid and some organics (e.g., Eastwood et al., 2009; Chernoff et al., 2010; Hoose and Möhler, 2012). According to these experiments, the onset ice supersaturation at which ice nucleation occurs (in the immersion mode of unactivated haze droplets) is substantially increased close to the liquid saturation point when mineral dust are coated with sulfuric acid compared to uncoated particles (in the deposition mode) at cold temperatures below $-30^{\circ} \mathrm{C}$. Sullivan et al. (2010) showed that the IN deactivation effect of sulphuric acid on mineral dust is irreversible and still effective once the acid has been neutralized with ammonia. Other than mineral dust, a small number of bioaerosols (bacteria, fungal spores, pollen, etc.) have been observed to nucleate ice at water-saturated conditions but at temperatures warmer than those observed at the top of TICs $\left(>-30^{\circ} \mathrm{C}\right.$ ) (Hoose and Möhler, 2012). Solid ammonium sulfate, sea salt, volcanic ash, some organic acids and soot particles are occasionally found to act as immersion/condensation nuclei at cold temperatures below $-30^{\circ} \mathrm{C}$ (Hoose and Möhler, 2012).

All these laboratory results suggest that IN activated in the upper part of TIC-1/2A identified by Jouan et al. (2012) are particles nucleating ice at a $\mathrm{RH}_{\text {Ice }}$ less than $120 \%$, such as mineral dust not covered with an acid and/or organic solution, while IN activated in the upper part of TIC-2B identified in Jouan et al. (2012) are particles nucleating ice at a $\mathrm{RH}_{\text {Ice }}$ greater than $120 \%$ at low temperatures $\left(<-30.0^{\circ} \mathrm{C}\right)$, such as acidified mineral dust, solid ammonium sulphate or soot particles. Once the process of ice nucleation initiates, low concentrations of IN combine to the high supersaturated air with respect to ice, leading to an explosive growth of ice crystals by water vapor diffusion. As a result, the TIC-2B is composed essentially of a relatively low concentration of precipitating ice crystals whereas the TIC-1/2A is composed of a top layer of small ice crystals in relatively large concentrations, which slowly grows to precipitating sizes by water vapor diffusion, followed by collision processes.

The North Pacific Ocean and Alaska are regions where mineral particles potentially act as IN in the atmosphere since they are frequently transported from desert areas in China (Uno et al., 2009) and volcanic regions such as the Aleutian Islands (Alaska, USA) or the Kamchatka Peninsula (Russia) (Yalcin et al., 2002). During their long-range transport, mineral dust particles can be coated with organic and inorganic solutions (Usher et al., 2003). Bigg (1980) found that much of the aerosol particles (including dust particles) measured at Barrow (Alaska) during winter 1977 and spring 1978 were covered with sulfuric acid. Prenni et al. (2009) studied the chemical composition of measured IN during the MixedPhase Arctic Cloud Experiment (M-PACE) campaign, which took place in the NSA in autumn 2004. The dominant particle types identified as IN were metal oxides/dust, carbonaceous particles and mixtures of metal oxides/dust with either carbonaceous components or salts/sulphates.

The long-range transport of mid-latitudes anthropogenic pollution is the major source of wintertime and springtime aerosol in the Arctic. A winter-spring maximum is known as Arctic haze (Uttal et al., 2002; Law and Stohl, 2007; Hirdman et al., 2010). Sulphate (compounds including the $\mathrm{SO}_{4}^{-2}$ 
ion) is the dominant component of these pollutant-enriched aerosols (Barrie and Barrie, 1990; Quinn et al., 2007). Volcanic emissions (releasing sulphate precursor sulfur dioxide $\left(\mathrm{SO}_{2}\right)$ ), oxidation of biogenic dimethyl sulfide (DMS) and open biomass burning are also important natural sources of sulphate pollution (Fisher et al., 2011; Warneke et al., 2009). $\mathrm{SO}_{2}$ must be oxidized to form sulphate before playing a role in aerosol nucleation and the modification of existing particles. The chemical transformation of $\mathrm{SO}_{2}$ to sulphate in the atmosphere can occur via gas-phase oxidation (cloudfree air) with the hydroxyl radical $(\mathrm{OH})$ and/or via oxidation in the aqueous phase (cloud droplets or pre-existing aerosols) with hydrogen peroxide $\left(\mathrm{H}_{2} \mathrm{O}_{2}\right)$, ozone $\left(\mathrm{O}_{3}\right)$, and iron catalysis as terminating reactions. These reactions are considered to be the most important sulfur dioxide oxidation pathways on a global scale (Seinfeld and Pandis, 1998). The rates of $\mathrm{SO}_{2}$ oxidation processes are influenced by many factors such as photochemistry, temperature, atmospheric conditions (especially high relative humidity) and concentration and composition of particulate matter (Seinfeld and Pandis, 1998) - and also determine the $\mathrm{SO}_{2}$ lifetime in the atmosphere. Once the $\mathrm{SO}_{2}$ gets into the cold, dry, arctic air, the residence time of $\mathrm{SO}_{2}$ increases. When $\mathrm{SO}_{2}$ is released into the atmosphere, around $46-82 \%$ of the $\mathrm{SO}_{2}$ emitted undergoes chemical transformations and forms sulphate while the rest is lost through dry and wet deposition (IPCC, 2001; Chin et al., 2000). According to Seinfeld and Pandis (1998), $\mathrm{SO}_{2}$ is chemically active and has a relatively short average atmospheric lifetime of $\sim 2$ days, while sulphate-containing aerosols have an average lifetime of $\sim 4-5$ days (Adams et al., 1999).

In this paper, the origin of the air masses in which the ISDAC TIC-1/2A (1 April 2008) and TIC-2B form (15 April 2008), as identified by Jouan et al. (2012), is investigated to verify the hypothesis regarding the potential link between acidified mineral dust and TIC-2B, considering information gathered from the ARCTAS (Arctic Research of the Composition of the Troposphere from Aircraft and Satellites, April 2008, Alaska) (Jacob et al., 2010), ISDAC field experiments and trajectory analyses. This paper is organized as follows. In Sect. 2, temporal variability of Alaskan averaged sulfur dioxide pollution from satellite data is presented with the meteorological conditions associated during March through April 2008. Sections 3 and 4 list the main potential sources of sulfur dioxide and the transport pathways into Alaska during this reporting period, using a Lagrangian approach with the FLEXPART model for the study of longrange transport. Detailed analyses of sources and characteristics of air masses measured during ISDAC for TIC-1/2A and TIC-2B and reported in an earlier paper by Jouan et al. (2012) are described in Sect. 5. Results are discussed by examining the CALIPSO satellite tracks, which intersect the back trajectories in the region away from the airborne measurements. A discussion and conclusions are presented in Sects. 6 and 7, respectively.

\section{Alaskan pollution and meteorological conditions in April 2008}

Satellite measurements provide complementary information on the atmospheric abundance of various gas species. In this study, the ability of the ultraviolet and visible spectrometer OMI (Ozone Monitoring Instrument), on board the NASA's Earth Observing System (EOS)-Aura satellite, was used to detect sulfur dioxide. Aura is a polar orbiting satellite with a nadir ground footprint of $13 \times 24 \mathrm{~km}^{2}$ and a $2600 \mathrm{~km}$ cross track swath providing daily and contiguous global mapping of the trace gas species.

$\mathrm{SO}_{2}$ column data are derived using the band residual difference (BRD) algorithm (Krotkov et al., 2006) and the linear fit (LF) algorithm (Yang et al., 2007). These algorithms use the $\mathrm{SO}_{2}$ absorption bands between 310 and $360 \mathrm{~nm}$ to retrieve the column density of $\mathrm{SO}_{2}$.

For this study, the OMI level $2 \mathrm{G}$ daily gridded $\left(0.125 \times 0.125^{\circ}\right)$ for the mid-tropospheric (between 5 to $10 \mathrm{~km}$ ) $\mathrm{SO}_{2}$ products (TRM OMI L2G SO 2 ) are used to assess qualitatively the temporal variability of $\mathrm{SO}_{2}$ over the study area of Alaska. OMI L2G $\mathrm{SO}_{2}$ products were acquired using the GES-DISC Interactive Online Visualization ANd aNalysis Infrastructure (GIOVANNI) developed by the NASA Goddard Earth Sciences (GES) Data and Information Services Center (DISC). OMI L2G SO 2 products were filtered to remove data with high radiative cloud fraction (>0.3), large solar zenith angle $\left(>70^{\circ}\right)$ and anomalous scenes. Data include only those for which the GIOVANNI quality flags bit 0 was not set, and thus defined as "good data" (GIOVANNI website: http://disc.sci.gsfc.nasa.gov/giovanni/ overview/index.html). The total $\mathrm{SO}_{2}$ column density is given in Dobson units $\left(1 \mathrm{DU}=2.69 \times 10^{16}\right.$ molecules $\left.\mathrm{cm}^{-2}\right)$. For example, the standard deviation of TRM retrievals in background areas is about $0.3 \mathrm{DU}$ at mid-latitudes. Both the bias and standard deviation increase with solar zenith angle.

Recent validation of OMI total $\mathrm{SO}_{2}$ column density measurements confirms that the OMI is an effective tool for evaluation of anthropogenic and natural $\mathrm{SO}_{2}$ emissions. Good qualitative agreement was found between airborne and OMI measurements for the low altitude anthropogenic sources (Krotkov et al., 2008) as well as strong quantitative agreement between ground-based, airborne and OMI measurements for both eruptive and non-eruptive volcanic emissions at higher altitudes (Spinei et al., 2010; Lopez et al., 2012). However, in each case, the analyses were performed just above the area of emission of $\mathrm{SO}_{2}$, putting aside the question of the ability of the OMI to discriminate sources of $\mathrm{SO}_{2}$. Preliminary surveys of volcanic $\mathrm{OMI} \mathrm{SO}_{2}$ data indicate that the OMI's detection limit for high latitude and springtime conditions varies from $\sim 2000$ to 4000 tons of sulfur dioxide emitted per day (Lopez et al., 2012). Detection of weaker sources usually requires temporal averaging of the $\mathrm{OMI} \mathrm{SO}_{2}$ data. 


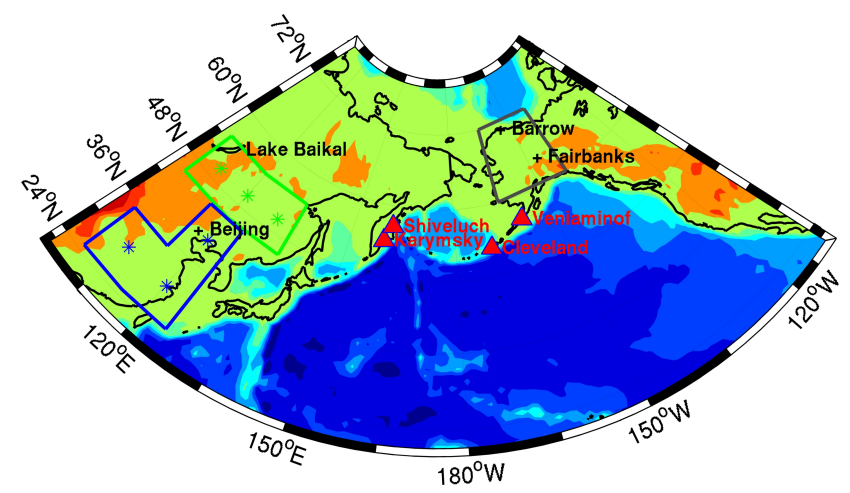

Fig. 1. Study area: Alaska $\left[195-220^{\circ} \mathrm{W} ; 60-72^{\circ} \mathrm{N}-\right.$ in gray $]$ and domains of potential $\mathrm{SO}_{2}$ emission to Alaska used for the FLEXPART simulations; the northeastern China anthropogenic emission [AE - in blue]; the southeastern Russia biomass burning emission [BBE - in green] and the volcanic emission [VE - in red] from the Kamchatka Peninsula and Aleutians. Red triangles show positions and names of active volcanoes during April 2008.

The daily variability of the area-averaged $\mathrm{SO}_{2}$ total column above Alaska (studied area can be seen in Fig. 1) in mid-troposphere from 27 March to 25 April 2008 is shown in Fig. 2. As already mentioned above, most of the differences between TICs are located near the cloud top where the nucleation of ice crystals is most likely to occur, which is why the $\mathrm{SO}_{2}$ concentrations observed by $\mathrm{OMI}$ in the mid-troposphere will be used. Two mean periods were distinguished. Period A (27 March-9 April) is characterized by a relatively low concentration of $\mathrm{SO}_{2}$ in the range of 0 to 0.12 DU. Period $\mathrm{B}$ (1025 April) is characterized by a concentration of $\mathrm{SO}_{2} 3$ times higher when compared to period $\mathrm{A}$, in the range of 0.06 to 0.39 DU. Atkinson et al. (2013) analyzed the temporal evolution of sulfur species over the period of 25 March through 30 April 2008 from a DRUM impact sampler system operating at $50 \mathrm{~km}$ north of Fairbanks, Alaska. In agreement with the OMI results, the authors notice a low concentration of sulfur $\left(<50 \mathrm{ng} \mathrm{m}^{-3}\right)$ during the first week of April followed by a period of high concentration of sulfur 2-4 times higher than the first week from 7 to 29 April 2008.

During period A.1 (27 March-2 April), the synoptic pattern was dominated by the presence of a main low-pressure system over the Siberian coast (above the Laptev Sea) with a series of low-pressure systems forming over Japan and moving slowly north northeastward toward the Bering Sea (see Fig. 3a). This synoptic pattern sets up a flow trajectory directed initially to eastern China/Siberia, carrying on east northeastward toward the Aleutians into Alaska. During period A.2 (3-9 April), the main low-pressure system moved up into Alaska; the latter, combined with the anticyclone in the central North Pacific, pushes the Asian exit flow eastward without passing through Alaska from 3-9 April 2008 (see Fig. 3b). Period B (10-25 April) was dominated by two distinct synoptic patterns. From 10 to 16 April (period B.1),

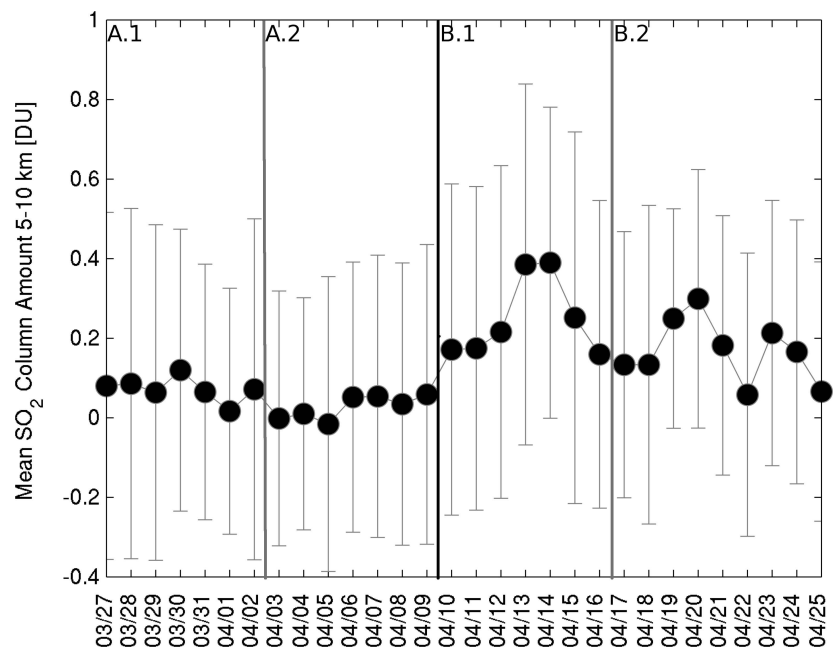

Fig. 2. Daily variability of the area-averaged $\mathrm{SO}_{2}$ total column above Alaska (Fig. 1) from 27 March to 25 April 2008 based on an assumed $\mathrm{SO}_{2}$ altitude between 5 to $10 \mathrm{~km}$ (TRM OMI L2G SO products). Vertical lines represent the standard deviation. Results should be considered preliminary estimates.

the weakening of the low-pressure system over Alaska and the persistence of the high-pressure system in the central North Pacific allow the establishment of a more zonal pattern in the north that pushes the Asian exit flow northwards into Alaska and the Siberian exit flow directly eastward into Alaska (see Fig. 3c). Between 17 and 25 April (period B.2), the anticyclone in the central North Pacific was split into two weaker high-pressure systems by the incursion of a lowpressure system between them. Further north, the combination of a low-pressure system from the west into the Kamchatka/Aleutians with a high-pressure system into Alaska took place (see Fig. 3d). This leads to the formation of a pressure ridge, thus increasing the transport distance between northeastern China/southeastern Siberia and Alaska. These results suggest that the synoptic conditions encountered during periods A.1, B.1 and B.2 favor air mass transport from eastern Asia/Siberia to Alaska via the volcanic area, with a longer travel time during period B.2. However, the synoptic pattern of period A promotes air mass transport over a long distance above the North Pacific Ocean, providing opportunity for aerosol loss by wet deposition into the marine convective boundary layer, whereas the time of air masses spent over the ocean is significantly shorter during period B. This could explain the high concentration of $\mathrm{SO}_{2}$ accumulated during period B above Alaska compared to period A.

\section{Potential sources of $\mathrm{SO}_{2}$ pollution in Alaska}

The average column density of $\mathrm{SO}_{2}$ over April 2008 from anthropogenic sources over the Northern Hemisphere is shown in Fig. 4. In this study, the OMI Level 3G 

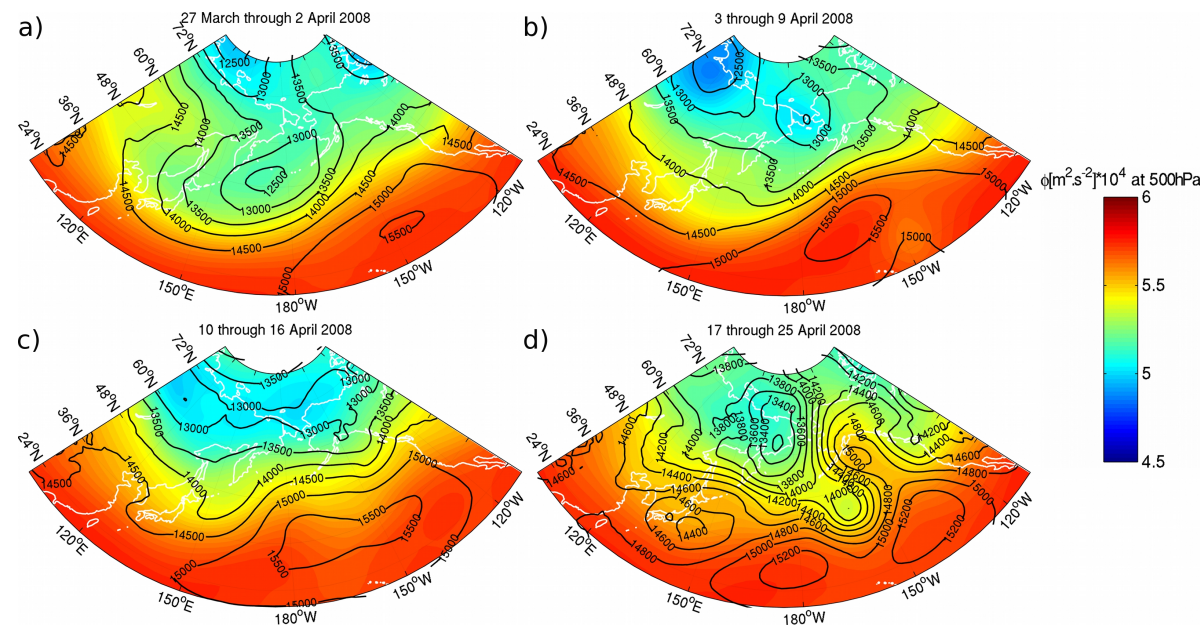

Fig. 3. Mean geopotential $\left(\mathrm{m}^{2} \mathrm{~s}^{-2}\right.$ ) at $850 \mathrm{hPa}$ (contour) and $500 \mathrm{hPa}$ (color bar) from 27 March to 2 April (a), 3 to 9 April (b), 10 to 16 April (c) and 17 to 25 April (d) 2008.

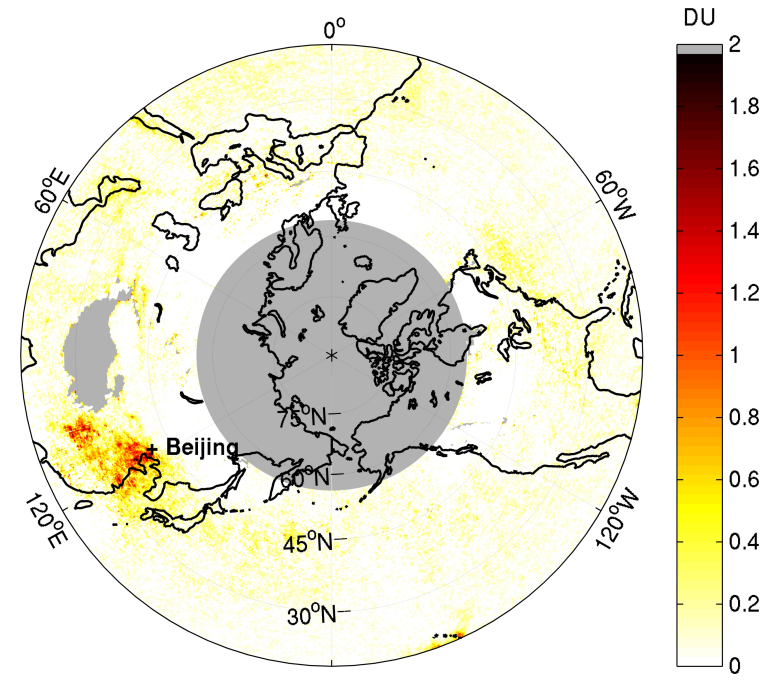

Fig. 4. Monthly mean $\mathrm{SO}_{2}$ total column based on an assumed $\mathrm{SO}_{2}$ altitude below $2 \mathrm{~km}$ (PBL OMI L3 $\mathrm{SO}_{2}$ products) over the Northern Hemisphere in April 2008.

daily gridded $\left(0.25 \times 0.25^{\circ}\right)$ for the planetary boundary layer (PBL - below $2 \mathrm{~km}$ ) $\mathrm{SO}_{2}$ products (PBL OMI L3G $\mathrm{SO}_{2}$ ) (available at http://disc.sci.gsfc.nasa.gov/Aura/ data-holdings/OMI/omso2e_v003.shtml) are used to study qualitatively the anthropogenic sources. OMI $\mathrm{L}_{3} \mathrm{G} \mathrm{SO}_{2}$ products correspond to the PBL OMI $22 \mathrm{G} \mathrm{SO}_{2}$ products filtered for clouds and post-corrected using the methodology of Lee et al. (2009). The standard deviation for this product is $\sim 1.5 \mathrm{DU}$ for instantaneous field-of-view of $\mathrm{PBL} \mathrm{SO}_{2}$ data, but temporal and spatial averaging can reduce the noise by one third. Given this large noise, only $\mathrm{SO}_{2}$ pollution from strong anthropogenic sources and from strong regional pollution can be detected in daily data (Carn et al., 2007; Krotkov

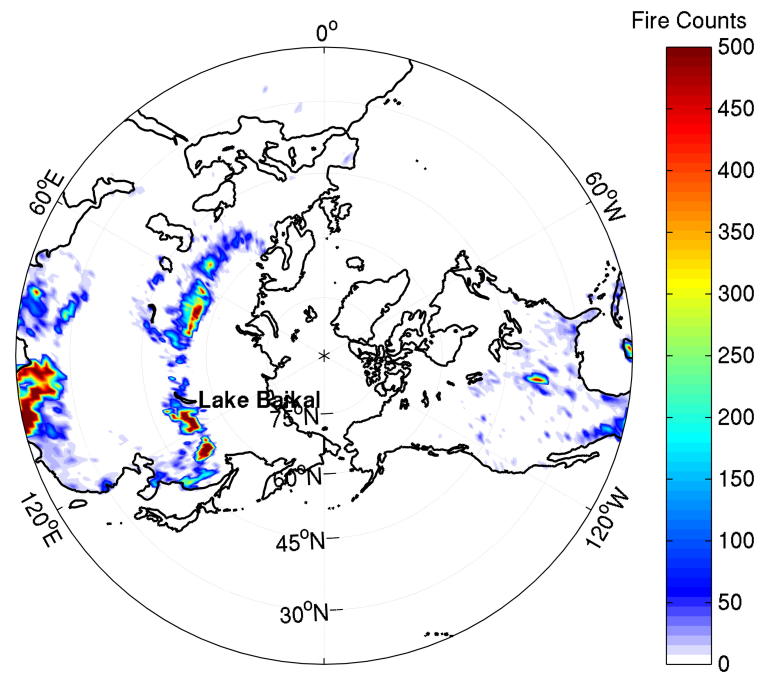

Fig. 5. Fire counts on April 2008 from the MODIS Aqua satellite instrument cloud- and overpass- corrected, over the Northern Hemisphere.

et al., 2008). The highest values (of more than 1.2 DU) are found over eastern China due to the abundance of coal power plants, its metal ores and smelting industries, and fossil fuel consumption in these regions. In April 2008, China was one of the largest contributing countries of sulfur dioxide in the Northern Hemisphere. Lu et al. (2010) estimated the annual $\mathrm{SO}_{2}$ emission of China to be around $\sim 32.1 \mathrm{Tg}$ in 2008 .

During the same period, intense biomass burning (BB) occurred in southern Russia/Kazakhstan and southeastern Siberia, mainly related to agricultural and boreal forest fires, respectively (Warneke et al., 2009, 2010). Figure 5 shows fire activity during April 2008 as indicated by the MODerate resolution Imaging Spectroradiometer (MODIS) fire counts (http://neespi.gsfc.nasa.gov/myd14 $\mathrm{cm} 1 . \mathrm{shtml}$ ) in the 
Northern Hemisphere. This product presents the total number of fire pixels observed in each grid cell, corrected for multiple satellite overpasses, missing observations, and variable cloud cover.

Observations from ARCTAS/ARCPAC (Aerosol, Radiation, and Cloud Processes affecting Arctic Climate, April 2008, Alaska) field experiments reveal that eastern Asian anthropogenic emissions and Russian fire emissions contributed to aerosol loading found over the North American Arctic (NAA) during the winter-spring season 2008 (Brock et al., 2011; Jacob et al., 2010; Harrigan et al., 2011). Fisher et al. (2011) found that eastern Asian anthropogenic sources were the largest contributors of sulphate through transport in the free troposphere, followed closely by the European anthropogenic sources contributions at all altitudes, during ARCTAS/ARCPAC projects.

Volcanoes are another significant natural source and provide emissions of sulphate throughout the troposphere that is not neutralized by natural ammonia emission, thus keeping a higher degree of acidity. There were some volcanic activities over the Aleutian Islands and Kamchatka Peninsula in winter-spring 2008. Continuous degassing activities were common from the Cleveland and Veniaminof volcanoes located in the Aleutians. In addition, sustained eruptive activities were recorded at the Karymsky and Shiveluch volcanoes located in the Kamchatka Peninsula (see Fig. 1). The Veniaminof and Cleveland volcanoes were monitored by the volcanologists of the Alaska Volcano Observatory (AVO). The Karymsky and Shiveluch volcanoes were monitored by the volcanologists of the Kamchatka Volcanic Eruption Response Team (KVERT). Using seismic data, satellite images and internet camera data, the daily volcano activity notifications on the websites of AVO (http://www.avo.alaska.edu) and KVERT (http://www.kscnet.ru) noted the presence of persistent activity in Aleutians volcanoes and reported several weak ash-and-gas explosions occurring daily during the reported period in Kamchatka volcanoes. It should be noted that monitoring volcanic eruptions is often challenging due to the remoteness of many of the volcanoes in the region, making a local monitoring network difficult to establish and maintain. Cloudy weather also regularly hinders the ability of satellites to measure $\mathrm{SO}_{2}$ content and thus detect related eruptions. For these reasons, it is very difficult to quantify the emission of $\mathrm{SO}_{2}$ above the volcanoes for a long period such as one month.

\section{Transport pathways}

Three regions of potential $\mathrm{SO}_{2}$ emissions to Alaska were defined in the previous section: the northeastern China anthropogenic emission (AE), the southeastern Siberia biomass burning emission (BBE), and the volcanic emission (VE) from the Kamchatka/Aleutians (see Fig. 1).
The distance to which highly polluted and possibly acidic air masses are transported largely depends on the atmospheric circulation and conditions. Dry and wet depositions and chemical reactions play an important role in gas and aerosol lifetimes. To assess the abundance and acidity of aerosols over Alaska in April 2008, one has to account for these factors.

In the current study, favorable periods of pollution transport are defined with the mean travel time from the three emission domains to the Alaska domain (see Fig. 1) during April 2008 using the Lagrangian Particle Dispersion Model (LPDM) FLEXPART version 6 (Stohl et al., 1998, 2002). FLEXPART was driven by meteorological input data from the 6-hourly European Center for Medium-Range Weather Forecasts (ECMWF) analysis interleaved with operational forecasts every $3 \mathrm{~h}$. In addition to classical advection, the LPDM includes turbulent diffusion, deposition and parameterizations of sub-grid scale convection. Results are discussed using forward trajectories to describe pollution transport to the Arctic. Ten-day forward trajectories were calculated with the FLEXPART model during the period of 22 March through 20 April 2008. The simulations were initialized each day at 12:00:00 UTC from 3 boxes in the AE domain and 3 boxes in the BBE domain. From the Kamchatka/Aleutians, five-day forward trajectories were calculated during the period of 27 March through 25 April 2008. The simulations were initialized each day at 12:00:00 UTC from 3 boxes located near the volcanoes of interest (VE). Box positions are shown using blue asterisks in Fig. 1. The height of all boxes was between 2000 and $2500 \mathrm{~m}$. The starting point of a FLEXPART forward trajectory is represented by a box with the following size: $0.5^{\circ}$ lat. $\times 0.5^{\circ}$ lon. $\times 500 \mathrm{~m}$ alt. For a selected box, 2000 particles are released during $60 \mathrm{~min}$. The dispersion is described by the position of 5 clusters, each containing associated fractions of particles. Tables 1, 2 and 3 give the travel time, the end point altitude/date and the fraction of particle reaching Alaska from the 3 boxes of the AE, BBE or VE domains each day. From 22 March to 20 April 2008, $4.9 \%$ of particles leaving the AE domain reached Alaska compared to $8.1 \%$ from the BBE domain. The average travel time of these trajectories to reach Alaska was about $6 \pm 2$ days (Tables 1 and 2). From 27 March to 25 April 2008, 32.2\% of particles leaving the 3 boxes of the VE domain reached Alaska in less than a day (Table 3). Considering the arrival date of particles from $\mathrm{AE}, \mathrm{BBE}$ and $\mathrm{VE}$ domains to Alaska (Table 1), it is noted that an average of $\sim 10-12 \%, \sim 10-20 \%$ and $\sim 37-50 \%$ per day of particles emitted, respectively, from $\mathrm{AE}, \mathrm{BBE}$ and VE domain boxes reached Alaska during periods A.1, B.1 and B.2, respectively. Almost no air mass emitted from the three domains reached Alaska during period A.2. These results, combined with the synoptic conditions described in the previous section, confirm that the low concentration of $\mathrm{SO}_{2}$ recorded by OMI during period A. 2 is due to unfavorable weather conditions for the transport of pollution into Alaska. 
Table 1. List of days on which FLEXPART simulated 10-day forward trajectories from the AE domain reached the Alaskan domain, with the particles' fraction, travel time, altitude and date of arrival associated with the end of March to the end of April 2008.

\begin{tabular}{|c|c|c|c|c|}
\hline \multicolumn{3}{|c|}{ Northeastern China Anthropogenic Emissions } & \multicolumn{2}{|c|}{ Total number of trajectories reaching Alaska $=4.3 \%$} \\
\hline Initial Date $\mathrm{d} / \mathrm{m} / \mathrm{y}$ & Trajectories $\mathrm{Nb}$ & Travel Time Days & Arrival Altitude km & Arrival Date d/m/y \\
\hline 22 Mar 2008 & 1 & 9 & 4.9 & 31 Mar 2008 \\
\hline 23 Mar 2008 & 3 & $8 \pm 1$ & $5.67 \pm 1.43$ & 31 Mar 2008 \\
\hline 25 Mar 2008 & 5 & $7 \pm 2$ & $5.76 \pm 0.03$ & 1 Apr 2008 \\
\hline 26 Mar 2008 & 4 & $7 \pm 2$ & $5.94 \pm 0.06$ & 2 Apr 2008 \\
\hline 27 Mar 2008 & 3 & 4 & $5.48 \pm 2.11$ & 31 Mar 2008 \\
\hline 28 Mar 2008 & 1 & 6 & 3.4 & 3 Apr 2008 \\
\hline 29 Mar 2008 & 1 & 4 & 7.26 & 2 Apr 2008 \\
\hline 30 Mar 2008 & 3 & $4 \pm 1$ & $6.24 \pm 0.10$ & 3 Apr 2008 \\
\hline 31 Mar 2008 & 1 & 4 & 7.26 & 4 Apr 2008 \\
\hline 5 Apr 2008 & 1 & 6 & 2.94 & 11 Apr 2008 \\
\hline 6 Apr 2008 & 2 & 8 & $2.9 \pm 0.01$ & 15 Apr 2008 \\
\hline 8 Apr 2008 & 1 & 5 & 3.9 & 13 Apr 2008 \\
\hline 9 Apr 2008 & 3 & $5 \pm 3$ & $5.78 \pm 1.69$ & 14 Apr 2008 \\
\hline 11 Apr 2008 & 6 & $5 \pm 2$ & $4.42 \pm 1.32$ & 16 Apr 2008 \\
\hline 12 Apr 2008 & 2 & $8 \pm 1$ & $6.95 \pm 4.13$ & 20 Apr 2008 \\
\hline 13 Apr 2008 & 1 & 3 & 4.9 & 16 Apr 2008 \\
\hline 14 Apr 2008 & 6 & $6 \pm 1$ & $9.03 \pm 1.59$ & 20 Apr 2008 \\
\hline 15 Apr 2008 & 1 & 9 & 4.46 & 24 Apr 2008 \\
\hline 16 Apr 2008 & 2 & $6 \pm 2$ & $7.28 \pm 2.99$ & 22 Apr 2008 \\
\hline 17 Apr 2008 & 4 & 9 & 6.8 & 26 Apr 2008 \\
\hline 18 Apr 2008 & 1 & 6 & 6.46 & 24 Apr 2008 \\
\hline \multirow[t]{2}{*}{20 Apr 2008} & 7 & $5 \pm 2$ & $6.66 \pm 1.57$ & 25 Apr 2008 \\
\hline & Mean & $6.03 \pm 2.08$ & $6.04 \pm 1.93$ & \\
\hline
\end{tabular}

Table 2. List of days on which FLEXPART simulated 10-day forward trajectories from the BBE domain reached the Alaskan domain, with the particles' fraction, travel time, altitude and date of arrival associated with the end of March to the end of April 2008.

\begin{tabular}{|c|c|c|c|c|}
\hline \multicolumn{3}{|c|}{ Southeastern Russia Biomass Burning Emissions } & \multicolumn{2}{|c|}{ Total number of trajectories reaching Alaska $=13.1 \%$} \\
\hline Initial Date $\mathrm{d} / \mathrm{m} / \mathrm{y}$ & Trajectories $\mathrm{Nb}$ & Travel Time Days & Arrival Altitude km & Arrival Date $\mathrm{d} / \mathrm{m} / \mathrm{y}$ \\
\hline 23 Apr 2008 & 1 & 8 & 4.72 & 31 Mar 2008 \\
\hline $24 \operatorname{Mar} 2008$ & 1 & 7 & 4.42 & 31 Mar 2008 \\
\hline 25 Apr 2008 & 2 & $8 \pm 1$ & $5.29 \pm 0.99$ & 2 Apr 2008 \\
\hline 26 Mar 2008 & 2 & $4 \pm 1$ & $4.63 \pm 0.39$ & 30 Mar 2008 \\
\hline 2 Apr 2008 & 1 & 8 & 4.15 & 10 Apr 2008 \\
\hline 3 Apr 2008 & 2 & $8 \pm 1$ & $3.30 \pm 1.45$ & 11 Apr 2008 \\
\hline 6 Apr 2008 & 2 & $6 \pm 1$ & $3.45 \pm 0.82$ & 12 Apr 2008 \\
\hline 7 Apr 2008 & 1 & 9 & 3.16 & 16 Apr 2008 \\
\hline 8 Apr 2008 & 4 & $5 \pm 1$ & $3.04 \pm 8.46$ & 13 Apr 2008 \\
\hline 9 Apr 2008 & 1 & 8 & 3.21 & 17 Apr 2008 \\
\hline 11 Apr 2008 & 1 & 8 & 2.72 & 19 Apr 2008 \\
\hline 12 Apr 2008 & 6 & $6 \pm 1$ & $3.33 \pm 1.79$ & 18 Apr 2008 \\
\hline 13 Apr 2008 & 5 & $4 \pm 1$ & $4.65 \pm 0.27$ & 17 Apr 2008 \\
\hline 14 Apr 2008 & 4 & $2 \pm 1$ & $5.29 \pm 0.20$ & 16 Apr 2008 \\
\hline 16 Apr 2008 & 2 & $8 \pm 1$ & $5.10 \pm 0.47$ & 14 Apr 2008 \\
\hline 17 Apr 2008 & 1 & 8 & 4.48 & 25 Apr 2008 \\
\hline \multirow[t]{2}{*}{18 Apr 2008} & 3 & $4 \pm 1$ & $7.30 \pm 1.37$ & 22 Apr 2008 \\
\hline & Mean & $5.67 \pm 2.25$ & $4.33 \pm 1.47$ & \\
\hline
\end{tabular}


Table 3. List of days on which FLEXPART simulated 5-day forward trajectories from the VE domain reached the Alaskan domain, with the particles' fraction, travel time, altitude and date of arrival associated with the end of March to the end of April 2008.

\begin{tabular}{|c|c|c|c|c|}
\hline \multicolumn{3}{|c|}{ Volcanic Emission } & \multicolumn{2}{|c|}{ Total number of trajectories reaching Alaska $=32.3 \%$} \\
\hline Initial Date $d / m / y$ & Trajectories $\mathrm{Nb}$ & Travel Time Days & Arrival Altitude km & Arrival Date $\mathrm{d} / \mathrm{m} / \mathrm{y}$ \\
\hline 27 Mar 2008 & 3 & $2 \pm 1$ & $2.08 \pm 0.07$ & 29 Mar 2008 \\
\hline 28 Mar 2008 & 10 & 1 & $2.87 \pm 1.09$ & 29 Mar 2008 \\
\hline 29 Mar 2008 & 10 & 0 & $2.76 \pm 0.40$ & 29 Mar 2008 \\
\hline 30 Mar 2008 & 10 & 1 & $1.95 \pm 0.61$ & 31 Mar 2008 \\
\hline 31 Mar 2008 & 10 & $1 \pm 1$ & $2.48 \pm 0.22$ & 1 Apr 2008 \\
\hline 1 Apr 2008 & 9 & $2 \pm 1$ & $1.79 \pm 0.83$ & 3 Apr 2008 \\
\hline 2 Apr 2008 & 5 & 0 & $3.04 \pm 0.26$ & 2 Apr 2008 \\
\hline 3 Apr 2008 & 10 & $1 \pm 1$ & $2.70 \pm 0.28$ & 4 Apr 2008 \\
\hline 9 Apr 2008 & 6 & $2 \pm 1$ & $2.80 \pm 1.18$ & 11 Apr 2008 \\
\hline 11 Apr 2008 & 3 & $1 \pm 1$ & $4.07 \pm 0.77$ & 12 Apr 2008 \\
\hline 14 Apr 2008 & 3 & $3 \pm 1$ & $1.85 \pm 0.14$ & 17 Apr 2008 \\
\hline 15 Apr 2008 & 9 & $2 \pm 2$ & $2.51 \pm 1.12$ & 17 Apr 2008 \\
\hline 16 Apr 2008 & 10 & $1 \pm 1$ & $1.19 \pm 0.40$ & 17 Apr 2008 \\
\hline 17 Apr 2008 & 6 & 0 & $2.75 \pm 0.40$ & 17 Apr 2008 \\
\hline 18 Apr 2008 & 10 & 0 & $2.46 \pm 0.16$ & 18 Apr 2008 \\
\hline 19 Apr 2008 & 5 & 0 & $2.18 \pm 0.29$ & 19 Apr 2008 \\
\hline 22 Apr 2008 & 6 & $1 \pm 1$ & $2.48 \pm 0.62$ & 23 Apr 2008 \\
\hline 23 Apr 2008 & 5 & 0 & $2.29 \pm 0.22$ & 23 Apr 2008 \\
\hline 24 Apr 2008 & 10 & 1 & $3.13 \pm 0.43$ & 25 Apr 2008 \\
\hline \multirow[t]{2}{*}{25 Apr 2008} & 5 & 0 & $3.73 \pm 0.80$ & 25 Apr 2008 \\
\hline & Mean & $0.89 \pm 1.06$ & $2.50 \pm 0.84$ & \\
\hline
\end{tabular}

The $\mathrm{OMI} \mathrm{SO}_{2} \mathrm{~L} 2 \mathrm{G}$ data were used to assess qualitatively the transport of $\mathrm{SO}_{2}$ in the free troposphere from anthropogenic and natural sources. Figure 6 shows the evolution and transport of the OMI total column density of $\mathrm{SO}_{2}$ in the mid-troposphere $(5-10 \mathrm{~km})$ for ISDAC periods A.1, A.2, B.1 and B.2 (Fig. 2), over the eastern part of Asia/Russia to Alaska. At first glance, a low concentration of $\mathrm{SO}_{2}$ is recorded by OMI in the mid-troposphere above the Kamchatka/Aleutians during period A.1 compared to the other three periods (Fig. 6a). More surprisingly, there is even a higher concentration of $\mathrm{SO}_{2}$ above the VE domain during period B.2 when a lower pollution rate is measured above the AE/BBE domains (Fig. 6d). These results suggest that volcanoes from Kamchatka/Aleutians were more active during periods A.2, B.1 and B.2 compared to period A.1. Therefore, the high concentration of $\mathrm{SO}_{2}$ recorded over Alaska during period $\mathrm{B}$ appears to be mostly of volcanic origin and therefore more acidic than during period A.1.

However, it is difficult to discriminate the $\mathrm{SO}_{2}$ sources in the Alaskan area knowing that the air masses likely have been influenced by the three defined $\mathrm{SO}_{2}$ sources. The observed variations can originate from changes in source intensity and/or from interactions and modification processes during transport. When lifted to the free troposphere (higher than $2000 \mathrm{~m}$ ), the atmospheric $\mathrm{SO}_{2}$ has a longer lifetime, and the long-range transport of atmospheric $\mathrm{SO}_{2}$ from China, for example, becomes more efficient (Tu et al., 2004). It is, how- ever, expected that part of tropospheric $\mathrm{SO}_{2}$ is removed by dry deposition or oxidization to form sulphate aerosols during transport to Alaska. He et al. (2012) investigated the budget and transport of $\mathrm{SO}_{2}$ and sulphate in central and eastern China in April 2008 using the Community Multiscale Air Quality (CMAQ) model to simulate sulfur chemistry. Numerical simulations indicate that $\sim 50 \%$ of the anthropogenic sulfur emissions were transported downwind, and the overall lifetime of tropospheric $\mathrm{SO}_{2}$ was $38 \pm 7 \mathrm{~h}$, which may cause a more difficult detection of $\mathrm{SO}_{2}$ after 2-3 days by OMI. Therefore, cloud processing and wet deposition should also be considered as possible sources of modification during transport.

\section{Polluted air masses - Arctic ice cloud interactions: case studies}

\subsection{ISDAC specific cases: overview and methodology}

Two ice clouds representing each type of TICs observed during the ISDAC campaign were investigated in detail by Jouan et al. (2012). The TIC-1/2A on flight F9 (TIC-1/2A-F9), associated with a warm front, was observed over the Barrow site on 1 April 2008 from 23:13:43 UTC to 23:45:43 UTC, corresponding to the relatively clean period A.1 identified in Sect. 2. The TIC-2B on flight F21 (TIC-2B-F21), in the 


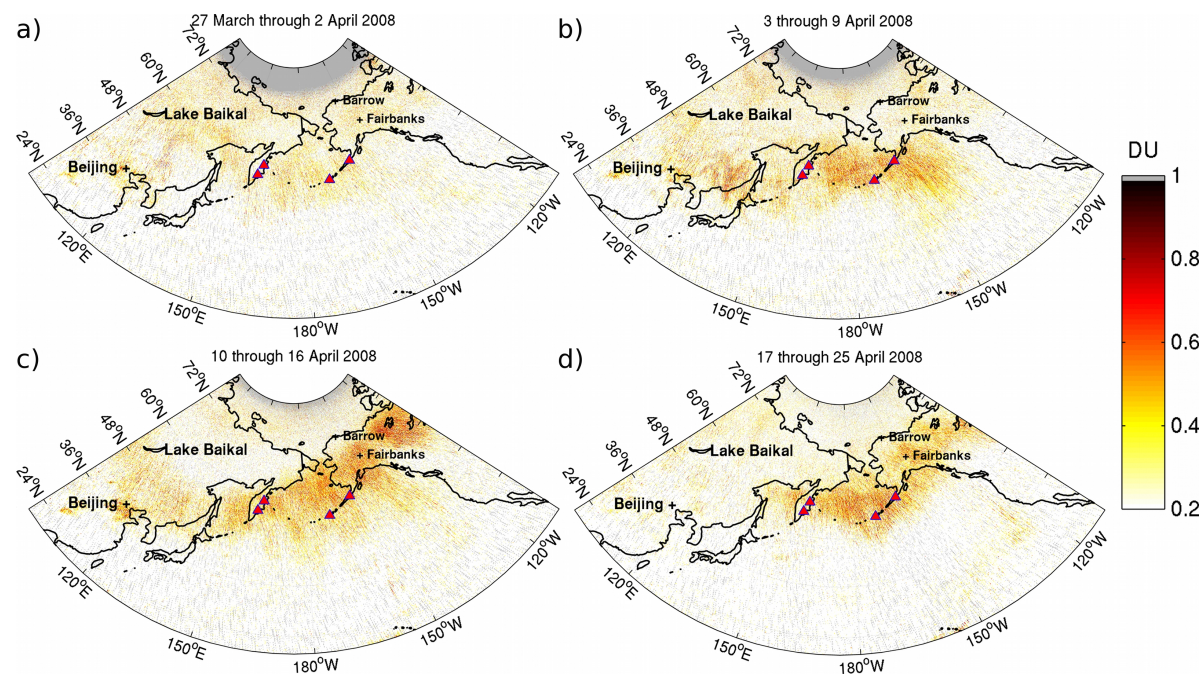

Fig. 6. Mean $\mathrm{SO}_{2}$ total column based on an assumed $\mathrm{SO}_{2}$ altitude between 5 to $10 \mathrm{~km}$ (TRM OMI L2G SO 2 products) from $27 \mathrm{March}$ to 2 April (a), 3 to 9 April (b), 10 to 6 April (c) and 17 to 25 April (d) 2008.

center of a decaying low-pressure system, was observed on 15 April 2008 from 00:55:26 UTC to 01:17:23 UTC, corresponding to period B.1, which is heavily loaded with $\mathrm{SO}_{2}$, as identified in Sect. 2.

In this section, the origin of the different observed air masses from which the TIC-1/2A-F9 and TIC-2B-F21 form is investigated in greater detail.

During the ISDAC field experiment, the National Research Council of Canada (NRC) Convair-580 was equipped with 41 instruments, including aerosol sensors. The aerosol number concentration $(\mathrm{Na})$ was measured with $\mathrm{CPC}-3775$ $(>0.004 \mu \mathrm{m})$ and PCASP $(0.12-3 \mu \mathrm{m})$ probes. Note that data from the CPC-3775 were valid for lower altitudes only ( $<3.5 \mathrm{~km}$ above mean sea level) due to instrument limitation. Data from the PCASP were missing for the studied flight F21. A single mass spectrometer (SPLAT-II) measuring the concentration and chemical composition of aerosols (Zelenyuk et al., 2010) and a continuous flow diffusion chamber (CFDC) measuring the IN concentration were also available on the aircraft. Unfortunately, the CFDC was not functional for flights prior to 8 April 2008 (including flights 8-15) and aerosol chemical composition from SPLAT-II for studied flights F9 and F21 were not available at the beginning of the analysis (A. Zelenyuk, personal communication, 2011). To compensate this lack of in situ aerosol observations, this paper proposes an alternative approach to determine the potential acidity of the studied air masses.

Results are discussed examining the CALIPSO satellite tracks, which intersect the back trajectories in the region away from the TICs layers observed by the aircraft and/or satellites to analyze aerosol occurrence and optical properties. The objective is to investigate in depth the link between TIC-2B formation and acidified mineral dust using a Lagrangian approach previously developed by de Villiers et al. (2010). It will be briefly described here. Both spiral profiles of flights F9 and F21 were divided into 13 boxes between $1 \mathrm{~km}$ and $7.5 \mathrm{~km}$ in altitude $\left(500 \mathrm{~m} \times 0.5^{\circ} \times 0.5^{\circ}\right)$. The focus was put on the origin of air masses near the top of the cloud (zt_TIC-1/2A-F9 $=6.65 \mathrm{~km}$ and $\mathrm{zt}_{-} \mathrm{TIC}-2 \mathrm{~B}-\mathrm{F} 21=6.75 \mathrm{~km}$ altitude from ISDAC airborne measurements - see Jouan et al., 2012), where most of the differences between the two clouds were found (Jouan et al., 2012). For a selected box, 2000 particles were released for $60 \mathrm{~min}$. The particles dispersion was computed every $24 \mathrm{~h}$ during several days backward in time prior to the measurements and described by the average position of 5 clusters. Tables 1 and 2 show that the eastern Asian trajectories had an average travel time of about $6 \pm 2$ days to reach Alaska. Then, for each box, the particles dispersion was computed for 9 days backward in time. The size of the clusters corresponds to the number of particles included in the cluster and the color corresponds to its altitude. The color of the mean trajectory of the particles represents the altitude of the ending point. Air mass trajectory estimates remain coherent when the 5 clusters (or at least the largest ones) stay close to each other (e.g., Fig. 7). CALIPSO tracks were selected when the time and horizontal position of the satellite overpass was less than $2 \mathrm{~h}$ and $200 \mathrm{~km}$, respectively, from air mass positions estimates by the FLEXPART simulations (e.g., Fig. 8). The variational synergistic algorithm (Varcloud) developed by Delanoë and Hogan (2008) was used here to identify cloud and aerosol properties. This algorithm combines radar and lidar observations to retrieve the ice water content (IWC), extinction and ice crystal effective radius $\left(R_{\mathrm{e}}\right)$ in regions of the cloud detected by both instruments. These operational products are called DARDAR (raDAR/liDAR) and are available at the data center ICARE (http://www.icare.fr) in France. More details on DARDAR can be found in Delanoë and 

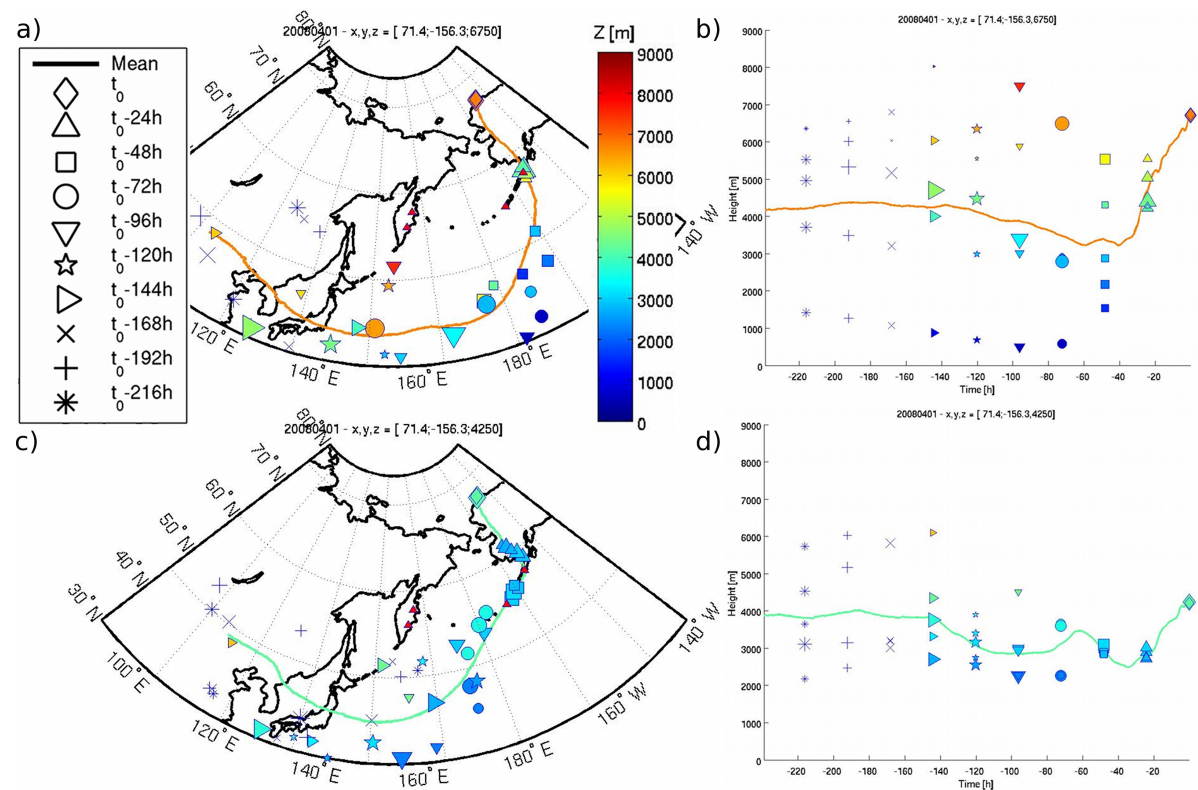

Fig. 7. 10-days backward trajectories from FLEXPART simulations initialized on 1 April 2008 at 23:14:00 for boxes located at 71.4 ${ }^{\circ}$, $156.3^{\circ} \mathrm{W}$ at $6.75 \mathrm{~km}$ height $\left[B_{\mathrm{F} 9} 1\right](\mathbf{a}, \mathbf{b})$ and $4.25 \mathrm{~km}$ height $\left[B_{\mathrm{F} 9} 2\right](\mathbf{c}, \mathbf{d})$. Clusters of particles are represented every $24 \mathrm{~h}$ from the beginning of the simulation. The color bar represents the altitude of cluster in meters. Particles are released during one hour.

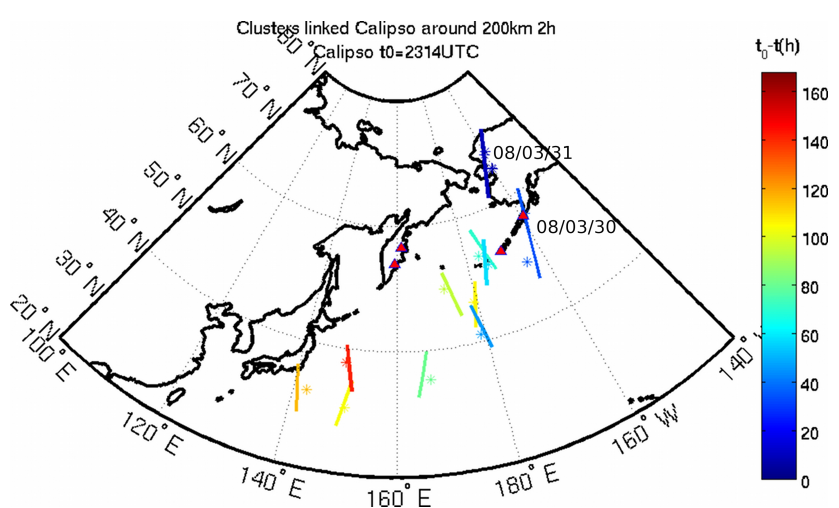

Fig. 8. CALIPSO track sections (line) and FLEXPART air mass positions $\left({ }^{*}\right)$ along FLEXPART trajectories initialized in the boxes $B_{\mathrm{F} 9} 1$ and $B_{\mathrm{F} 9} 2$ of Fig. $7 \mathrm{a}$ and c. The color scale indicates the elapsed time in hours between the CALIPSO observation and the aircraft observation.

Hogan (2008, 2010). Jouan et al. (2012) demonstrated the ability of DARDAR to identify ice clouds of type TIC-1/2A and TIC-2B observed during the ISDAC campaign. Taking the A-Train overpass track closest in time and space from the studied ISDAC profiles F9 and F21 (discussed below), they quantified the mean values of $T, \beta_{\text {att }}, Z$, IWC and $\mathrm{R}_{\mathrm{e}}$ retrieved from the Varcloud algorithm as a function of the normalized altitude of ice cloud layers within the TIC-1/2A and the TIC-2B. The ratio IWC/ $R_{\mathrm{e}}$ was also calculated to get a representation of the ice particle number concentration in the cloud; mean values are presented in Table 4. The op- erational CALIOP aerosol data (version 3.01) were also used along the selected CALIPSO track. These products provided the optical properties of aerosol layers averaged every $5 \mathrm{~km}$ horizontally (Liu et al., 2009). Two additional criteria are considered: the layers detected only at a horizontal resolution of $80 \mathrm{~km}$ and an optical thickness at $532 \mathrm{~nm}$ over 0.03 . These two conditions are needed to identify aerosol layers with low optical depths (de Villiers, 2010). All aerosol layers discussed in this section have a cloud-aerosol discrimination (CAD) greater than $90 \%$, which ensures that the detected layer by CALIOP contained aerosols (Eguchi et al., 2009).

\subsection{April 2008 - TIC-1/2A-F9 ice cloud}

On the TIC-1/2A-F9 profile, the transport pathway for the ensemble of 2000 particles released for two boxes, $B_{\mathrm{F} 9} 1$ and $B_{\mathrm{F} 9} 2$, are shown in Fig. 7. They are respectively characterized by their geographical coordinates in latitude, longitude, and their altitude: $B_{\mathrm{F} 9} 1\left(71.4^{\circ} \mathrm{N}, 156.3^{\circ} \mathrm{W}, 6.75 \mathrm{~km}\right)$ and $B_{\mathrm{F} 9} 2\left(71.4^{\circ} \mathrm{N}, 156.3^{\circ} \mathrm{W}, 4.25 \mathrm{~km}\right)$. Air masses $B_{\mathrm{F} 9} 1$ and $B_{\mathrm{F} 9} 2$ originate 6 to 7 days before from eastern China/Siberia. They follow on average the tracks reports in Fig. $7 \mathrm{a}$ and $\mathrm{b}$ and Fig. $7 \mathrm{c}$ and d, respectively. This synoptic pattern corresponds to period A.1 described in Sect. 2, e.g., dominated by a direction of flow from the western North Pacific Ocean into Alaska. Throughout the pathway from eastern China/Siberia to the Aleutians, air masses stay at an altitude ranging from 3 to $4 \mathrm{~km}$ before rising over Alaska in their northward track. Particles in box $B_{\mathrm{F} 9} 1$ more importantly rise (about $4 \mathrm{~km}$ ) from 31 March to the observation time on 1 April at the top 
Table 4. $T, \beta, Z$, IWC, $R_{\mathrm{e}}$ and IWC / $R_{\mathrm{e}}$ from Varcloud algorithm of different ice cloud layers defined in Figs. 9 and 12 with their associated standard deviation, according to the normalized altitude.

\begin{tabular}{|c|c|c|c|c|c|c|c|}
\hline $\begin{array}{l}\text { Cloud Layer } \\
\text { (CL) }\end{array}$ & $z / z t$ & $\begin{array}{r}T \\
\left({ }^{\circ} \mathrm{C}\right)\end{array}$ & $\left(\log _{10} \mathrm{sr}^{-1} \mathrm{~m}^{-1}\right)$ & $\begin{array}{r}Z \\
(\mathrm{dBZ})\end{array}$ & $\begin{array}{r}\text { IWC } \\
\left(10^{-3} \mathrm{~g} \mathrm{~m}^{-3}\right)\end{array}$ & $\begin{array}{r}R_{\mathrm{e}} \\
(\mu \mathrm{m})\end{array}$ & $\begin{array}{r}\mathrm{IWC} / \mathrm{R}_{\mathbf{e}} \\
\left(\mathrm{g} \mathrm{m}^{-4}\right)\end{array}$ \\
\hline $\begin{array}{l}\text { TIC-1/2A-F9 } \\
\text { Lat: } 71.0-71.5^{\circ} \mathrm{N} \\
\mathrm{zt}=7.60 \mathrm{~km}\end{array}$ & $\begin{array}{l}{[1.0-0.9]} \\
{[0.9-0.8]} \\
{[0.8-0.7]} \\
{[0.7-0.6]}\end{array}$ & $\begin{array}{l}-44.0 \pm 2.0 \\
-38.1 \pm 1.9 \\
-32.1 \pm 2.0 \\
-26.3 \pm 1.8\end{array}$ & $\begin{array}{l}-5.31 \pm 0.20 \\
-5.25 \pm 0.09 \\
-5.45 \pm 0.06 \\
-5.45 \pm 0.05\end{array}$ & $\begin{array}{l}-30.0 \pm 2.3 \\
-22.7 \pm 1.9 \\
-16.7 \pm 2.0 \\
-12.2 \pm 1.2\end{array}$ & $\begin{array}{l}14.31 \pm 5.41 \\
23.04 \pm 4.77 \\
25.34 \pm 1.40 \\
28.14 \pm 2.55\end{array}$ & $\begin{array}{l}27.6 \pm 1.2 \\
33.6 \pm 2.5 \\
40.7 \pm 2.2 \\
46.6 \pm 1.9\end{array}$ & $\begin{array}{r}514.8 \pm 191.1 \\
690.2 \pm 87.5 \\
616.2 \pm 63.5 \\
580.6 \pm 24.4\end{array}$ \\
\hline $\begin{array}{l}\mathrm{CL}_{\mathrm{F} 9} 1 \\
\text { Lat: } 56.3-56.7^{\circ} \mathrm{N} \\
\mathrm{zt}=9.72 \mathrm{~km}\end{array}$ & $\begin{array}{l}{[1.0-0.9]} \\
{[0.9-0.8]} \\
{[0.8-0.7]} \\
{[0.7-0.6]}\end{array}$ & $\begin{array}{l}-55.1 \pm 2.2 \\
-47.6 \pm 2.5 \\
-39.8 \pm 2.5 \\
-31.9 \pm 2.5\end{array}$ & $\begin{array}{l}-5.09 \pm 0.34 \\
-5.55 \pm 0.37 \\
-5.48 \pm 0.28 \\
-5.90 \pm 0.47\end{array}$ & $\begin{array}{r}-27.9 \pm 3.1 \\
-22.1 \pm 0.7 \\
-15.3 \pm 4.6 \\
-9.1 \pm 1.0\end{array}$ & $\begin{array}{r}12.4 \pm 5.9 \\
11.6 \pm 3.9 \\
21.5 \pm 12.0 \\
64.8 \pm 10.4\end{array}$ & $\begin{array}{l}30.0 \pm 2.0 \\
35.5 \pm 1.5 \\
42.8 \pm 3.2 \\
51.2 \pm 2.3\end{array}$ & $\begin{array}{l}400.2 \pm 183.2 \\
331.9 \pm 130.5 \\
479.3 \pm 239.0 \\
1148.3 \pm 93.7\end{array}$ \\
\hline $\begin{array}{l}\text { TIC-2-F21 } \\
\text { Lat: } 71.0-71.5^{\circ} \mathrm{N} \\
\mathrm{zt}=5.94 \mathrm{~km}\end{array}$ & $\begin{array}{l}{[1.0-0.9]} \\
{[0.9-0.8]} \\
{[0.8-0.7]} \\
{[0.7-0.6]}\end{array}$ & $\begin{array}{l}-41.3 \pm 0.6 \\
-38.8 \pm 1.1 \\
-34.7 \pm 1.5 \\
-30.6 \pm 1.2\end{array}$ & $\begin{array}{l}-5.69 \pm 0.11 \\
-5.59 \pm 0.10 \\
-5.31 \pm 0.09 \\
-5.46 \pm 0.14\end{array}$ & $\begin{array}{l}-30.0 \pm 2.0 \\
-21.6 \pm 3.5 \\
-12.8 \pm 1.8 \\
-14.0 \pm 2.3\end{array}$ & $\begin{array}{r}3.81 \pm 0.93 \\
6.09 \pm 2.15 \\
15.70 \pm 2.75 \\
12.08 \pm 3.33\end{array}$ & $\begin{array}{l}36.8 \pm 1.0 \\
41.7 \pm 2.4 \\
49.4 \pm 2.0 \\
49.4 \pm 1.8\end{array}$ & $\begin{array}{l}104.3 \pm 25.6 \\
143.0 \pm 39.0 \\
310.5 \pm 45.2 \\
238.7 \pm 59.0\end{array}$ \\
\hline $\begin{array}{l}\mathrm{CL}_{\mathrm{F} 21} 1 \\
\text { Lat: } 66.5-67.0^{\circ} \mathrm{N} \\
\mathrm{zt}=7.62 \mathrm{~km}\end{array}$ & $\begin{array}{l}{[1.0-0.9]} \\
{[0.9-0.8]} \\
{[0.8-0.7]} \\
{[0.7-0.6]}\end{array}$ & $\begin{array}{l}-48.2 \pm .2 .2 \\
-40.9 \pm 2.3 \\
-34.1 \pm 2.0 \\
-28.6 \pm 1.5\end{array}$ & $\begin{array}{l}-5.81 \pm 0.14 \\
-5.67 \pm 0.08 \\
-5.48 \pm 0.27 \\
-5.16 \pm 0.20\end{array}$ & $\begin{array}{l}-31.3 \pm 1.5 \\
-29.1 \pm 0.9 \\
-22.1 \pm 5.7 \\
-11.4 \pm 1.8\end{array}$ & $\begin{array}{r}3.07 \pm 0.78 \\
3.91 \pm 0.31 \\
6.71 \pm 3.95 \\
22.66 \pm 3.49\end{array}$ & $\begin{array}{l}33.2 \pm 1.2 \\
36.2 \pm 0.8 \\
41.8 \pm 3.7 \\
50.9 \pm 1.1\end{array}$ & $\begin{array}{r}91.5 \pm 20.5 \\
108.8 \pm 9.6 \\
155.4 \pm 75.4 \\
440.5 \pm 62.6\end{array}$ \\
\hline $\begin{array}{l}\mathrm{CL}_{\mathrm{F} 21} 2 \\
\mathrm{Lat}: 58.0-58.5^{\circ} \mathrm{N} \\
\mathrm{zt}=10.44 \mathrm{~km}\end{array}$ & $\begin{array}{l}{[1.0-0.9]} \\
{[0.9-0.8]} \\
{[0.8-0.7]} \\
{[0.7-0.6]}\end{array}$ & $\begin{array}{l}-54.5 \pm 2.4 \\
-46.0 \pm 2.6 \\
-37.9 \pm 2.5 \\
-30.3 \pm 2.1\end{array}$ & $\begin{array}{l}-5.93 \pm 0.23 \\
-5.50 \pm 0.09 \\
-5.49 \pm 0.07 \\
-5.51 \pm 0.09\end{array}$ & $\begin{array}{l}-30.4 \pm 1.7 \\
-23.6 \pm 2.9 \\
-18.4 \pm 0.8 \\
-11.1 \pm 3.8\end{array}$ & $\begin{aligned} 2.47 & \pm 0.86 \\
5.11 & \pm 1.00 \\
6.35 & \pm 0.35 \\
10.83 & \pm 4.71\end{aligned}$ & $\begin{array}{l}31.7 \pm 2.2 \\
38.2 \pm 2.2 \\
44.4 \pm 2.3 \\
58.7 \pm 6.4\end{array}$ & $\begin{aligned} 76.1 & \pm 24.2 \\
133.6 & \pm 17.4 \\
144.2 & \pm 14.6 \\
178.1 & \pm 57.4\end{aligned}$ \\
\hline
\end{tabular}

of the cloud around Barrow (see Fig. 7b), compared to particles in $B_{\mathrm{F} 9} 2$ box located $2.5 \mathrm{~km}$ below. This upward motion spreads over a large distance ahead of the warm front. According to $\mathrm{Tu}$ et al. (2004), $\mathrm{SO}_{2}$ transported at altitudes of 2-4 km from East Asia dominated the $\mathrm{SO}_{2}$ distribution in the central Pacific. In our case, $\mathrm{SO}_{2}$ concentrations appear to be smaller over the northern Pacific $\left(180^{\circ} \mathrm{W}\right.$ and 40 to $\left.60^{\circ} \mathrm{N}\right)$ in early April than later (see Fig. 6a). On 30 March, air masses $B_{\mathrm{F} 9} 1$ and $B_{\mathrm{F} 9} 2$ pass just above the volcanoes of the Aleutians (see Figs. 7 and 8). The daily volcano activity notifications of AVO reported weak volcanic tremors at Veniaminof at the end of March and a very weak thermal anomaly was detected at the summit of Cleveland on 30 March 2008.

Air masses $B_{\mathrm{F} 9} 1$ and $B_{\mathrm{F} 9} 2$ intercept twice the CALIPSO/CloudSat track on 31 and 30 March 2008, respectively at 13:50 and 13:05:00 UTC (Fig. 8). Figure 9 shows the vertical profiles of DARDAR masks of these two selected track sections. On 31 March 2008, air masses $B_{\mathrm{F} 9} 1$ and $B_{\mathrm{F} 9} 2$ were located at $68^{\circ} \mathrm{N}$ just in front of an extended ice cloud $\left(<68^{\circ} \mathrm{N}\right)$ and above a mixed-phase cloud $\left(65-72^{\circ} \mathrm{N}\right)$ (Fig. 9a). The slope of the ice cloud base between 64 and $68^{\circ} \mathrm{N}$ is associated with the arrival of the warm front over northern Alaska. One day before (30 March 2008), $B_{\mathrm{F} 9} 1$ air mass was located just in front of a high-level ice cloud $\left(<48^{\circ} \mathrm{N}\right)$, whereas the $B_{\mathrm{F} 9} 2$ air mass was located near the active Veniaminof volcano, in a cloudy area (identified $\mathrm{CL}_{\mathrm{F} 9} 1$ for cloud layer in Fig. 9b). Mean
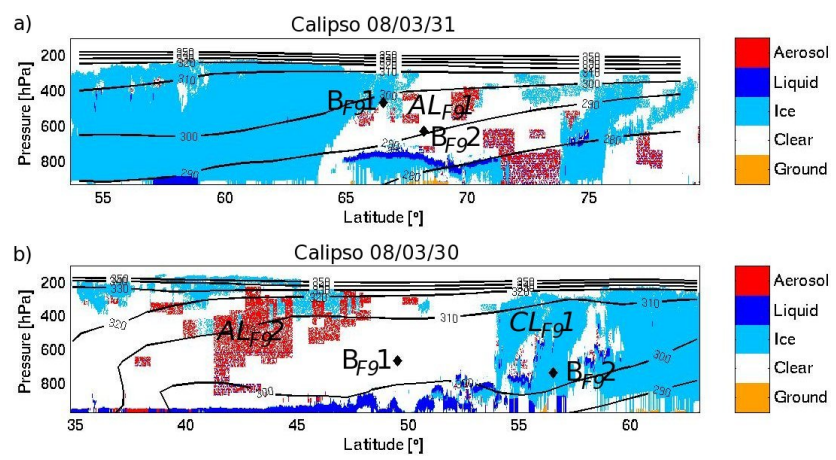

Fig. 9. DARDAR mask track section observed on 31 March (a) at 13:50:00 UTC and on 30 March (b) at 13:05:00 2008 from of the synergistic CloudSat radar and CALIPSO lidar, with FLEXPART air masses ( $B_{\mathrm{F} 9} 1$ and $\left.B_{\mathrm{F} 9} 2\right)$ positions $(\diamond)$.

values of $T, \beta_{\mathrm{att}}, Z$, IWC, $R_{\mathrm{e}}$ and IWC / $R_{\mathrm{e}}$ retrieved from the Varcloud algorithm along the normalized height of the extended ice cloud $\mathrm{CL}_{\mathrm{F} 9} 1\left(56.3-56.7^{\circ} \mathrm{N}\right)$ around box $B_{\mathrm{F} 9} 2$ are presented in Table 4 . With similar temperatures and ice water contents for the first $2 \mathrm{~km}$ at the top of ice clouds, the averaged $R_{\mathrm{e}}$ of the $\mathrm{CL}_{\mathrm{F} 9} 1$ ice cloud is comparable to the averaged $R_{\mathrm{e}}$ of the TIC-1/2A-F9 ice cloud with a ratio IWC $/ R_{\mathrm{e}}$ (index of ice crystals concentration) relatively 
high. $\mathrm{CL}_{\mathrm{F} 9} 1$ seems to belong to the category of TIC-1/2A with a high concentration of small ice crystals.

The CALIPSO/DARDAR mask independently reveals some aerosol layers near the $B_{\mathrm{F} 9} 1$ and $B_{\mathrm{F} 9} 2$ boxes between $65-74^{\circ} \mathrm{N}$ (identified $\mathrm{AL}_{\mathrm{F} 9} 1$ in Fig. 9a) in the midtroposphere on 31 March and a wide aerosol layer (identified $\mathrm{AL}_{\mathrm{F} 9} 2$ in Fig. 9b) over southern Aleutians volcanoes between $41-52^{\circ} \mathrm{N}$ from 1 to $10 \mathrm{~km}$ in altitude on 30 March 2008.

The mean attenuated backscatter coefficient at $532 \mathrm{~nm}$ $\left(\beta_{\text {att }}\right)$, the mean volume depolarization ratio at $532 \mathrm{~nm}\left(\delta_{\mathrm{v}}\right)$ and the mean attenuated total color ratio $\left(\mathrm{CR}_{\mathrm{att}}\right)$ for each aerosol layer are shown in Table 5. CALIPSO level 2 aerosol layer data at $5 \mathrm{~km}$ resolution were used. The volume depolarization ratio $\left(\delta_{\mathrm{v}}\right)$ in CALIOP products in aerosol layers is the ratio of the contributions in the backscattering direction of both molecules and particulates in a volume of the cross-polarization to total signals. The attenuated total color ratio $\mathrm{CR}_{\text {att }}$ is derived from the attenuated backscatter ratio between $1064 \mathrm{~nm}$ and $532 \mathrm{~nm}$. The relative variation in $\delta_{\mathrm{v}}$ and $\mathrm{CR}_{\text {att }}$ go in the same direction as that of the particulate color ratio between $1064 \mathrm{~nm}$ and $532 \mathrm{~nm}\left(\mathrm{CR}_{\mathrm{p}}\right)$ and the particulate depolarization ratio at $532 \mathrm{~nm}\left(\delta_{\mathrm{p}}\right)$, but with a lower amplitude with decreasing optical thickness and values of fractions of aerosol accumulation mode. The volume depolarization ratio, $\delta_{\mathrm{v}}$, as the attenuated total color ratio, $\mathrm{CR}_{\mathrm{att}}$, has the advantage of being less unstable than particulate parameters $\left(\delta_{\mathrm{p}}, \mathrm{CR}_{\mathrm{P}}\right)$ when studying thin aerosol layers, e.g., when the particular contribution is low (de Villiers, 2010). Uncertainties in $\delta_{\mathrm{v}}$ and $\mathrm{CR}_{\text {att }}$ are estimated to be about $10 \%$ and $30 \%$, respectively (de Villiers, 2010). The volume depolarization ratio $\left(\delta_{\mathrm{V}}\right)$ associated with $\mathrm{CR}_{\mathrm{att}}$ can qualitatively inform on the nature of the aerosol. $\delta_{\mathrm{v}}$ is sensitive to particle shape. Spherical aerosols (e.g., haze and aqueous smoke particles) produce little or no changes in the polarization state of backscattered light, whereas non-spherical particles like dust or volcanic ash can generate considerable depolarization (Mishchenko and Sassen, 1998; Atkinson et al., 2013). The relative increase in $\mathrm{CR}_{\text {att }}$ is related to the increase in particle size.

For both aerosol layers $\mathrm{AL}_{\mathrm{F} 9} 2$ and $\mathrm{AL}_{\mathrm{F} 9} 1, \beta_{\text {att }}$ and $\mathrm{CR}_{\text {att }}$ did not vary much between 30 to 31 March 2008 , with values of the order of $\beta_{\mathrm{att}}=1.3-1.4 \mathrm{Mm}^{-1} \mathrm{sr}^{-1}$ and $\mathrm{CR}_{\mathrm{att}}=0.26-$ 0.23 , respectively, while $\delta_{\mathrm{v}}$ decreased more steeply from 7 to $4 \%$ (Table 5). Following Liu et al. (2009), one can broadly characterize each of CALIOP individual aerosol layers as "dust" when the volume depolarization ration $\left(\delta_{\mathrm{v}}\right)$ is greater than $6 \%$ or as "non-dust" aerosol otherwise. The differences observed here remain small, however, and this differentiation may be difficult. However, the back-trajectory analysis (Fig. 7a, c) associated with the higher value of the depolarization ratio $(\sim 7 \%)$ (Table 5$)$ of the $\mathrm{AL}_{\mathrm{F} 9} 2$ aerosols layer on 30 March 2008 suggests that the aerosol layer is composed of dust coming from dry regions of China and Mongolia (Gobi Desert), probably mixed with anthropogenic pollution over eastern China (AE). The Tesche et al. (2009) and Giannakaki et al. (2012) approaches were used to separate mineral dust and non-dust (considered anthropogenic particles) contributions based on CALIOP lidar observations. CALIPSO level 2 aerosol profile data at $5 \mathrm{~km}$ resolution were used. Assuming that aerosols can be treated as two aerosol types externally mixed, the particulate backscatter contribution of the first aerosol type $\left(\beta_{\mathrm{p}, 1}\right)$ is obtained from the measured total particulate backscatter coefficient $\left(\beta_{\mathrm{p}, \mathrm{t}}\right)$ by the following equation:

$\beta_{\mathrm{p}, 1}=\beta_{\mathrm{p}, \mathrm{t}} \frac{\left(\delta_{\mathrm{p}, \mathrm{t}}-\delta_{\mathrm{p}, 2}\right)\left(1+\delta_{\mathrm{p}, 1}\right)}{\left(\delta_{\mathrm{p}, 1}-\delta_{\mathrm{p}, 2}\right)\left(1+\delta_{\mathrm{p}, \mathrm{t}}\right)}$,

where $\delta_{\mathrm{p}, \mathrm{t}}, \delta_{\mathrm{p}, 1}$ and $\delta_{\mathrm{p}, 2}$ are the observed total particulate depolarization ratio and the assumed particulate depolarization ratios of the two pure aerosol types, respectively. The backscatter coefficient of the second aerosol type is given by the following equation: $\beta_{\mathrm{p}, 2}=\beta_{\mathrm{p}, \mathrm{t}}-\beta_{\mathrm{p}, 1}$ (2).

The separation procedure, Eq. (1), was applied with dust aerosol representing aerosol type 1 and anthropogenic aerosol (non-dust aerosol) representing aerosol type 2. A value $\delta_{\mathrm{p}, 1}=0.35$ was considered for particulate depolarization ratio at $532 \mathrm{~nm}$ of Asian dust (Sugimoto et al., 2003; Shimizu et al., 2004). Non-dust particulate depolarization ratios $\delta_{\mathrm{p}, 2}$ can vary from 0.02 to 0.15 with an accumulation around 0.05 (Sugimoto et al., 2003; Tesche et al., 2009). The value $\delta_{\mathrm{p}, 2}=0.05$ was considered for the aerosol type 2 , as we suppose that transport over the ocean may induce increased moistening. Figure 10 shows the total particulate backscatter $\left(\beta_{\mathrm{p}, \mathrm{t}}\right)$, the total particulate depolarization ratio at $532 \mathrm{~nm}$ $\left(\delta_{\mathrm{p}, \mathrm{t}}\right)$, and the profiles of the dust (yellow) and anthropogenic (red) backscatter coefficient separated by this analysis with the CALIOP scene classification algorithm of the aerosols layer $\mathrm{AL}_{\mathrm{F} 9} 2$. The separation procedure reveals that the lower layer $(<3 \mathrm{~km}$ altitude), with a lower particulate depolarization ratio, is mixed while the middle and upper layers consist mainly of dust particles (Fig. 10d). The CALIOP scene classification algorithm classifies a thin aerosol layer (1$2 \mathrm{~km}$ altitude) as polluted dust and the middle and upper aerosol layers as dust (Fig. 10e). Polluted dust is designed to account for episodes of dust mixed with biomass burning smoke and/or anthropogenic pollution, which is consistent with the results. The following aerosol layer $\mathrm{AL}_{\mathrm{F} 9} 1$, on $31 \mathrm{March}$, has a value $\mathrm{CR}_{\text {att }} \sim 0.23$ and a value $\delta_{\mathrm{v}}<6 \%$. The CALIOP scene classification algorithm classifies the aerosol layer $\mathrm{AL}_{\mathrm{F} 9} 1$ as clean continental (Table 5). De Villiers (2010) notes that the CALIOP scene classification tends to define layers encountered after several days of transport as clean continental in the Arctic, while the same analysis shows a connection with the Asian polluted sources. The decrease in $\delta_{\mathrm{v}}$ associated with the slight decrease in $\mathrm{CR}_{\text {att }}$ between $\mathrm{AL}_{\mathrm{F} 9} 2$ on 30 March and $\mathrm{AL}_{\mathrm{F} 9} 1$ on 31 March can occur with the removal of the large particles by wet deposition just after the warm front at the time of cloud dissipation of clouds 
Table 5. Aerosol layer characteristics defined in previous figures from the CALIOP lidar observations.

\begin{tabular}{|c|c|c|c|c|c|c|}
\hline Aerosol Layer & $\mathrm{AL}_{\mathrm{F} 9} 1$ & $\mathrm{AL}_{\mathrm{F} 9} 2$ & $\mathrm{AL}_{\mathrm{F} 21} 1$ & $\mathrm{AL}_{\mathrm{F} 21} 2$ & $\mathrm{AL}_{\mathrm{F} 21} 3$ & $\mathrm{AL}_{\mathrm{F} 21} 4$ \\
\hline Date $(\mathrm{d} / \mathrm{m} / \mathrm{y})$ & 31 Mar 2008 & 30 Mar 2008 & 12 Apr 2008 & 12 Apr 2008 & 10 Apr 2008 & 10 Apr 2008 \\
\hline Time (UTC) & $13: 49-14: 29$ & $13: 11-13: 40$ & $14: 19-14: 48$ & $14: 18$ & $12: 53-13: 21$ & $12: 51-13: 23$ \\
\hline Start Lat/Lon $\left(^{\circ}\right)$ & $65.0 /-163.8$ & $41.3 / 174.4$ & $44.5 / 178.7$ & $62.0 /-178.3$ & $42.2 /-160.4$ & $52.0 /-156.1$ \\
\hline End Lat/Lon $\left(^{\circ}\right)$ & $71.0 /-156.7$ & $51.3 / 170.7$ & $51.0 /-178.7$ & $69.2 /-165.3$ & $52.0 /-156.6$ & $59.0 /-152.9$ \\
\hline $\mathrm{Z}_{\min }-\mathrm{Z}_{\max }(\mathrm{km})$ & $2.3-7.3$ & $1-11$ & $1.4-8.7$ & $1.4-7$ & $2-7.5$ & $2.5-8.5$ \\
\hline$\beta_{532, \mathrm{att}}\left(\mathrm{Mm}^{-1} \mathrm{sr}^{-1}\right)$ & $1.4 \pm 0.3$ & $1.3 \pm 0.4$ & $1.7 \pm 0.5$ & $1.7 \pm 0.4$ & $1.5 \pm 0.3$ & $1.5 \pm 0.3$ \\
\hline $\mathrm{CR}_{\mathrm{att}}$ & $0.23 \pm 0.38$ & $0.26 \pm 0.23$ & $0.31 \pm 0.21$ & $0.24 \pm 0.17$ & $0.27 \pm 0.17$ & $0.24 \pm 0.15$ \\
\hline$\delta_{\mathrm{V}}$ & $4 \pm 4$ & $7 \pm 4$ & $5 \pm 3$ & $3 \pm 3$ & $5 \pm 3$ & $4 \pm 3$ \\
\hline $\mathrm{CFC}$ & C.C & D & P.D & C.C & P.D & P.D \\
\hline$\beta_{532, \mathrm{p}, \mathrm{t}}\left(\mathrm{Mm}^{-1} \mathrm{sr}^{-1}\right)$ & - & $0.52 \pm 0.29$ & $0.50 \pm 0.30$ & - & $0.61 \pm 0.18$ & $0.65 \pm 0.28$ \\
\hline$\beta_{532, \mathrm{p}, 1}=$ Dust & - & $0.32 \pm 0.17$ & $0.27 \pm 0.18$ & - & $0.18 \pm 0.07$ & $0.15 \pm 0.09$ \\
\hline$\beta_{532, \mathrm{p}, 2}=$ Pollutant & - & $0.21 \pm 0.25$ & $0.24 \pm 0.24$ & - & $0.43 \pm 0.17$ & $0.50 \pm 0.27$ \\
\hline$\alpha_{\mathrm{p}, \mathrm{t}}\left(\mathrm{km}^{-1}\right)$ & $0.023 \pm 0.012$ & $0.021 \pm 0.012$ & $0.023 \pm 0.014$ & $0.024 \pm 0.012$ & $0.034 \pm 0.01$ & $0.038 \pm 0.02$ \\
\hline$\delta_{\mathrm{p}, \mathrm{t}}(\%)$ & $16 \pm 13$ & $24 \pm 10$ & $23 \pm 15$ & $10 \pm 5$ & $13 \pm 4$ & $12 \pm 7$ \\
\hline $\mathrm{RH}_{\text {Water }}(\%)$ & $49.7 \pm 15.8$ & $29.8 \pm 18.5$ & $59.0 \pm 17.5$ & $46.0 \pm 24.9$ & $38.0 \pm 18.2$ & $34.1 \pm 14.2$ \\
\hline
\end{tabular}
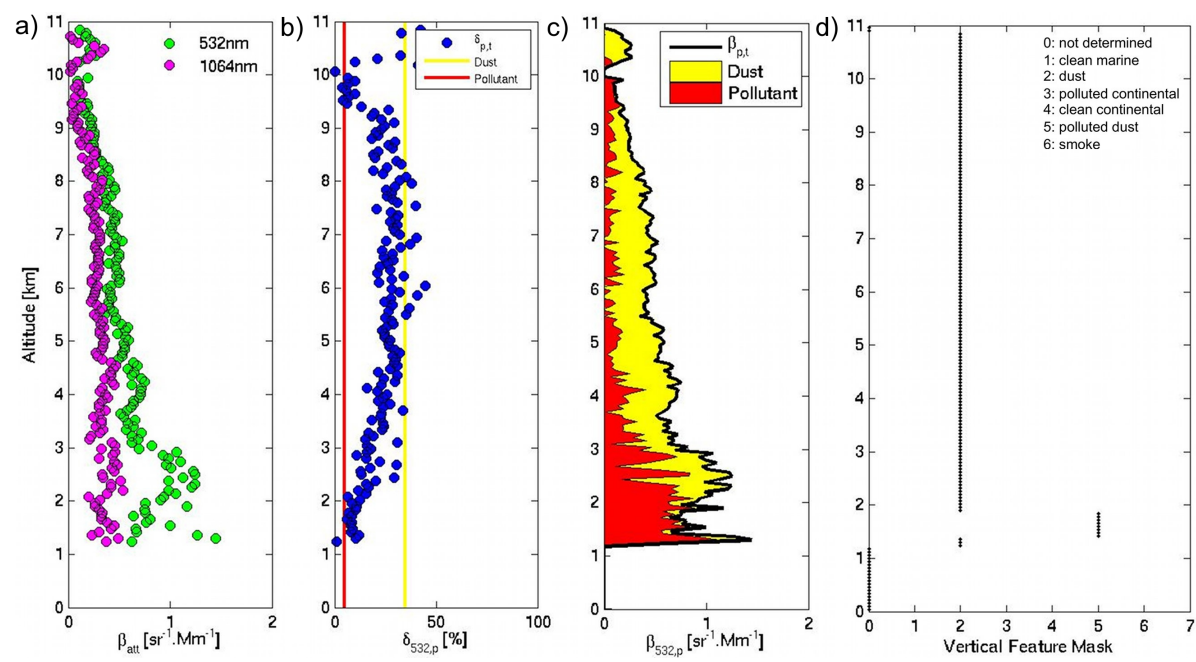

Fig. 10. (a) Total particulate backscatter coefficient at $532 \mathrm{~nm}$ (green) and $1064 \mathrm{~nm}$ (magenta), (b) total particulate depolarization ratio at $532 \mathrm{~nm}$ (green) and the input values of dust (yellow) and anthropogenic (red) particles, (c) separation of dust (yellow) and anthropogenic (red) particulate backscatter coefficients at $532 \mathrm{~nm}$, and (d) vertical feature mask as given by CALIPSO from aerosols layer $\left(\mathrm{AL}_{\mathrm{F} 9} 2\right)$ indicated in Fig. 9.

(Fig. 9a) (Bègue et al., 2012). The relative humidity with respect to water $\left(\mathrm{RH}_{\text {water }}\right)$ inside the $\mathrm{AL}_{\mathrm{F} 9} 2(\sim 29.8 \%)$ was drier than $\mathrm{AL}_{\mathrm{F} 9} 1(\sim 49.7 \%)$ (Table 5), thus supporting this hypothesis.

These results show that air masses observed within the upper part of the TIC-1/2A-F9 ice cloud were mainly influenced by pure dust from dry regions of China and Mongolia with some mixture of anthropogenic pollution (AE). With a large proportion of desert dust compared to anthropogenic aerosols, added to a low activity of volcanoes from Kamchatka/Aleutians (Fig. 6a), air masses forming the TIC-1/2AF9 can be classified as non-acidic.

\subsection{April 2008 - TIC-2B-F21 ice cloud}

On 15 April 2008 (TIC-2B-F21), the transport pathway for the ensemble of 2000 particles released for two boxes located at $5.75 \mathrm{~km}$ (hereafter $B_{\mathrm{F} 21} 1$ ) and $4.25 \mathrm{~km}$ (hereafter $B_{\mathrm{F} 21} 2$ ) located as before over Barrow $\left(71.5^{\circ} \mathrm{N} 156.6^{\circ} \mathrm{W}\right)$ are shown in Fig. 11. Air masses forming the TIC-2B-F21 come mainly from the Aleutians in a direct $\left(B_{\mathrm{F} 21} 1\right.$ in Fig. 11a) or a long transport path $\left(B_{\mathrm{F} 21} 2\right.$ in Fig. 11c). Due to the low-pressure system over Alaska, the air masses stay several days in the same area between $140^{\circ} \mathrm{E}-140^{\circ} \mathrm{W}$ and $45-75^{\circ} \mathrm{N}$ the 7 days prior to the observations. The $B_{\mathrm{F} 21} 1$ air mass comes directly from the Aleutians with an upward motion from the PBL (altitude $<2 \mathrm{~km}$ ) above the North Pacific Ocean 4 days before 

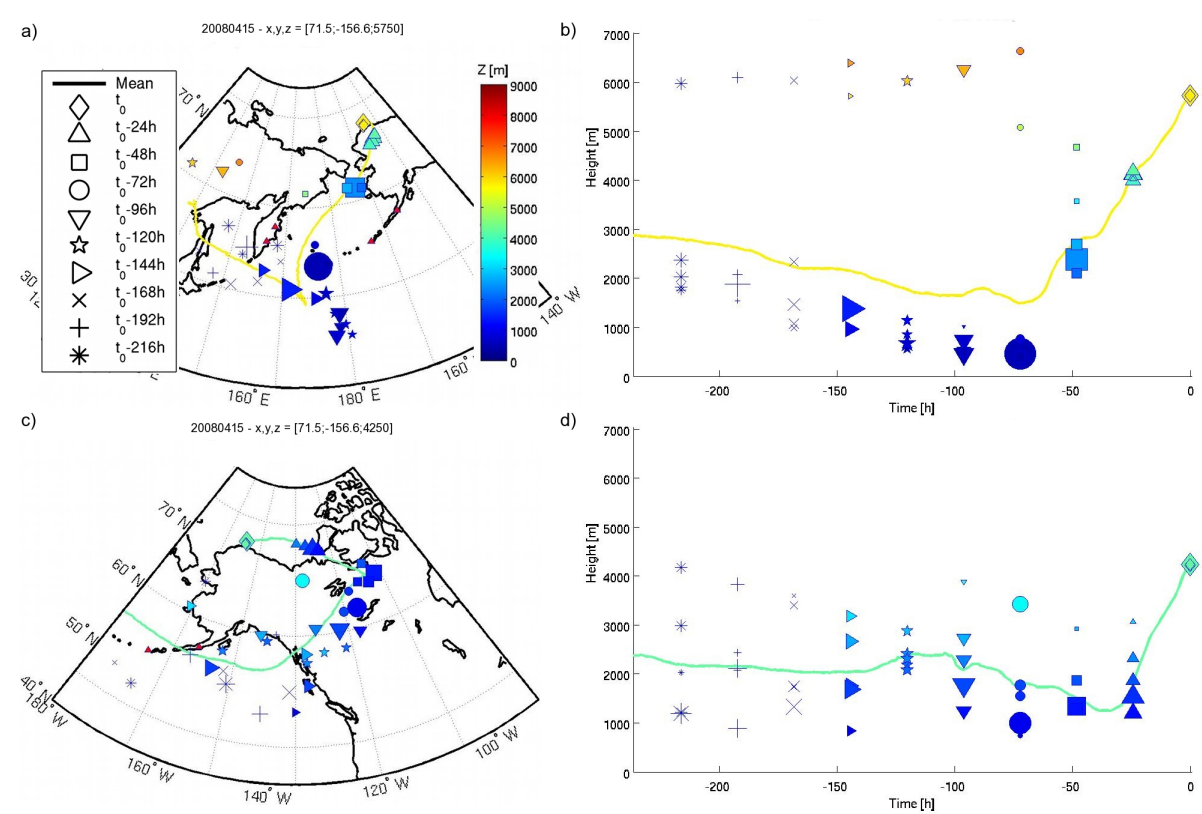

Fig. 11. 10-days backward trajectories from FLEXPART simulations initialized on 15 April 2008 at 01:16:00 UTC for boxes located at $71.5^{\circ} \mathrm{N}, 156.6^{\circ} \mathrm{W}$ at $(\mathbf{a}, \mathbf{b}) 5.75 \mathrm{~km}$ height $\left[B_{\mathrm{F} 21} 1\right]$ and $(\mathbf{c}, \mathbf{d}) 4.25 \mathrm{~km}$ height [ $\left.B_{\mathrm{F} 21} 2\right]$. Clusters of particles are represented every $24 \mathrm{~h}$ from the beginning of the simulation. The color bar represents the altitude of cluster in meters. Particles are released during one hour.

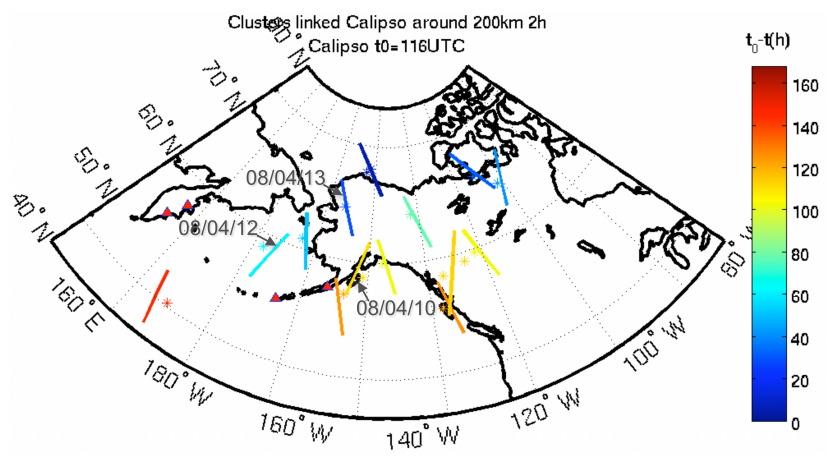

Fig. 12. CALIPSO track sections (line) and FLEXPART air mass positions $(*)$ along FLEXPART trajectories initialized in the box $B_{\mathrm{F} 21} 1$ of Fig. 11a (left of the dashed line) and initialized in the box $B_{\mathrm{F} 21} 2$ of Fig. 11c (right of the dashed line). The color scale indicates the elapsed time in hours between the CALIPSO observation and the aircraft observation.

(on 12 April 2008) at $175^{\circ} \mathrm{E}$ longitude and $50^{\circ} \mathrm{N}$ latitude (see Fig. 11b), to $\sim 5.75 \mathrm{~km}$ above the Bering Sea (3 days before) and the NSA (1-2 days before) (Fig. 11a). $B_{\mathrm{F} 21} 2$ air mass also comes from the Aleutians. It bypasses the low depression centered over Alaska, then passes over western Canada and comes back to Barrow with a northwest component. There is a significant upward motion from the PBL (altitude $<3 \mathrm{~km}$ ) to $4 \mathrm{~km}$ height above the Northwest Territories (2-3 days before) and the Beaufort Sea ( 1 day before) (see Fig. 11d). The OMI total $\mathrm{SO}_{2}$ columns density at $5 \mathrm{~km}$ from 10 to 16 April 2008 (see Fig. 6c) shows that the stud- ied $B_{\mathrm{F} 21} 1$ and $B_{\mathrm{F} 21} 2$ air masses passed through heavily $\mathrm{SO}_{2}$ $(>1.5 \mathrm{DU})$ polluted regions. Based on seismic and satellite data, the KVERT reported that weak ash-and-gas explosions may have occurred daily from the 10 to 14 April 2008 at Karymsky and Shiveluch (Kamchatka). $B_{\mathrm{F} 21} 1$ and $B_{\mathrm{F} 21} 2$ air masses stay at low altitudes when passing over and when moving away from the Aleutian Islands.

The back trajectories of the $B_{\mathrm{F} 21} 1$ and $B_{\mathrm{F} 21} 2$ air masses are further examined to identify the intercepts with CALIPSO and to look at other ice clouds with DARDAR. The trajectory of the $B_{\mathrm{F} 21} 1$ air mass crosses the CALIPSO satellite tracks three times in the three days preceding the observations (see Fig. 12). Figure 13a and b show the vertical profiles of cloud properties retrieved by DARDAR for the track sections on 13 and 12 April 2008, respectively at 23:01:00 and 14:18:00 UTC. On 13 April 2008, $B_{\mathrm{F} 21} 1$ air mass was located at $67^{\circ} \mathrm{N}$ inside an extended ice cloud between 58 and $72^{\circ} \mathrm{N}$ (identified as $\mathrm{CL}_{\mathrm{F} 21} 1$ ). On 12 April 2008, $B_{\mathrm{F} 21} 1$ air mass was located further south at $58.5^{\circ} \mathrm{N}$ inside a second extended ice cloud between 50 and $63^{\circ} \mathrm{N}$ (identified as $\mathrm{CL}_{\mathrm{F} 21} 2$ ). Table 4 shows the mean values of $T, \beta_{\text {att }}$, $Z$, IWC, $R_{\mathrm{e}}$ and IWC/ $R_{\mathrm{e}}$ along normalized height of extended ice cloud $\mathrm{CL}_{\mathrm{F} 21} 1\left(66.5-67^{\circ} \mathrm{N}\right)$ and $\mathrm{CL}_{\mathrm{F} 21} 2$ (58.0 $58.5^{\circ} \mathrm{N}$ ), around the $B_{\mathrm{F} 21} 1$ box. For both extended ice cloud layers $\mathrm{CL}_{\mathrm{F} 21} 1$ and $\mathrm{CL}_{\mathrm{F} 21}$, the ratio IWC/ $R_{\mathrm{e}}$ for the first $2 \mathrm{~km}$ at the top of ice clouds is as low as the TIC-2B-F21 ice clouds, for an averaged $R_{\mathrm{e}}$ also relatively high. $\mathrm{CL}_{\mathrm{F} 21} 1$ and $\mathrm{CL}_{\mathrm{F} 21} 2$ belong to the category of TIC-2B with a low concentration of large ice crystals. The CALIOP/DARDAR mask also reveals aerosol layers on either side of the ice cloud 

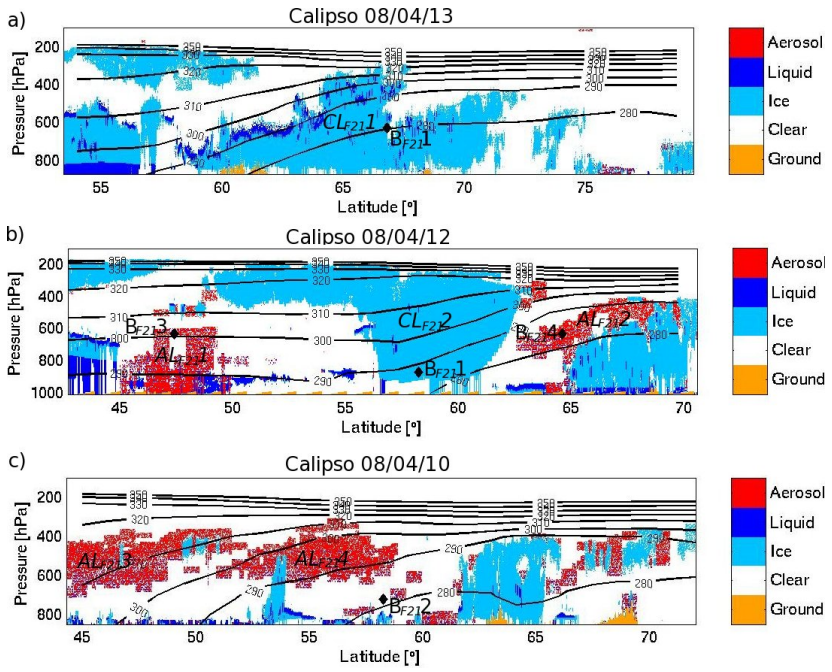

Fig. 13. DARDAR mask track section observed on 13 April (a) at 23:01:00 UTC and on 12 April (b) at 14:18:00 UTC that intercepts the FLEXPART air masses $\left(B_{\mathrm{F} 21} 1\right)$ in positions $(\checkmark)$, and on 10 April (c) at 13:00:00 UTC that intercepts the FLEXPART air masses $\left(B_{\mathrm{F} 21}\right)$ in positions $(\bullet)$.

$\mathrm{CL}_{\mathrm{F} 21} 2$, between $44-51^{\circ} \mathrm{N}$ above the North Pacific Ocean $\left(\mathrm{AL}_{\mathrm{F} 21} 1\right)$ and between $62-70^{\circ} \mathrm{N}$ just above the Bering Sea (AL $\left.\mathrm{F}_{21} 2\right)$ on 12 April 2008 (Fig. 13b). AL $\mathrm{F}_{\mathrm{F} 21} 1$ layer has low values of $\beta_{\text {att }}$ and $\mathrm{CR}_{\text {att }}$ of about $1.7 \mathrm{Mm}^{-1} \mathrm{sr}^{-1}$ and 0.31 with a volume depolarization ratio $\delta_{\mathrm{v}}$ of about $5 \pm 3 \%$ (Table 5). CALIOP scene classification algorithm classifies the $\mathrm{AL}_{\mathrm{F} 21} 1$ layer as polluted dust (Table 5). A 10-day backtrajectory analysis (Fig. 14a) of one air mass box $\left(B_{\mathrm{F} 21} 3\right)$ in the $\mathrm{AL}_{\mathrm{F} 21} 1$ layer $\left(47.4^{\circ} \mathrm{N}, 179.8^{\circ} \mathrm{E} ; 3.75 \mathrm{~km}\right.$ in Fig. $\left.13 \mathrm{~b}\right)$ reveals that the air mass comes from the dry regions of the Gobi Desert, probably mixed with anthropogenic pollution over eastern China (AE). The analysis in terms of partitioning between dust and non-dust, as previously done, shows that dust contributes to around $50 \%$ of scattering in the signal above $1 \mathrm{~km}$ (Fig. 15a and Table 5). The other aerosol layer $\mathrm{AL}_{\mathrm{F} 21} 2$ has lower $\delta_{\mathrm{V}}(3 \pm 3 \%)$ and is classified as a continental clean air mass (Table 5). A 10-day back-trajectory analysis (Fig. 14b) of an air mass box $\left(B_{\mathrm{F} 21} 4\right)$ inside the $\mathrm{AL}_{\mathrm{F} 21} 2$ layer $\left(64.6^{\circ} \mathrm{N}, 170.3^{\circ} \mathrm{W} ; 3.75 \mathrm{~km}\right.$ in Fig. $\left.13 \mathrm{~b}\right)$ reveals a contribution of biomass burning smoke.

The analysis in terms of the aerosol layer lidar properties that intercept the $B_{\mathrm{F} 21} 2$ air mass back trajectory (Figs. $11 \mathrm{e}$ and 12) with CALIPSO reveals that aerosol layers along the $B_{\mathrm{F} 21} 2$ (eastern part of Alaska) and $B_{\mathrm{F} 21} 1$ (western part of Alaska) air mass back trajectories seem to be relatively of the same composition. For example, the CALIPSO track section that intercepts the $B_{\mathrm{F} 21} 2$ air mass back trajectory on 10 April 2008 at $\sim$ 13:00:00 UTC (Fig. 12) reveals two aerosol layers between $44-60^{\circ} \mathrm{N}\left(\mathrm{AL}_{\mathrm{F} 21} 3\right.$ and $\mathrm{AL}_{\mathrm{F} 21} 4-$ Fig. 13c) above the Gulf of Alaska (Fig. 12). The analysis, in terms of partitioning between dust and non-dust as previ- ously done, shows a major (larger than $70 \%$ ) contribution of anthropogenic and/or biomass burning smoke scattering in the signal ( $\mathrm{AL}_{\mathrm{F} 21} 3$ and $\left.\mathrm{AL}_{\mathrm{F} 21} 4\right)$ (Table 5).

Air masses observed in Alaska on 15 April 2008 appear to be influenced by a mixture of Asian dust (with a $50 \%$ proportion of anthropogenic pollution) and/or biomass burning smoke (BBE) (with a $70 \%$ proportion of smoke). No signature of fresh volcanic ash (e.g., higher values of $\delta_{\mathrm{v}}$ due to the proximity) was found in the CALIOP data along back trajectories of $B_{\mathrm{F} 21} 1$ and $B_{\mathrm{F} 21} 2$ air masses forming the TIC2B-F21. Atkinson et al. (2013) show that, at the Fairbanks site, the second week of April (midday 5 to 17 April 2008) was dominated by Asian dust with some smoke probably resulting from a flow from northern China and southeastern Siberia, maintained by the presence of an anticyclone in the central North Pacific.

\section{Discussion}

This analysis of aerosol properties by back-trajectories FLEXPART gave some answers to the evaluation of the role of acidified mineral dust and the formations of TICs. Air masses forming both TICs were characterized by different sources of aerosols. Air masses forming the TIC-1/2A-F9 were composed of a high proportion of pure dust from dry regions of China and Mongolia with a low contribution of anthropogenic/smoke pollutants and $\mathrm{SO}_{2}$, suggesting the absence of highly acidic ice nuclei. The air masses forming the TIC-2B-F21 were composed of well-mixed polluted dust with a relatively high contribution of anthropogenic/smoke pollutants (more than $70 \%$ ) and $\mathrm{SO}_{2}$.

Asian dust contribution, as observed from the lidar signal analysis, appears comparable in both TICs cases, but the synoptic pattern observed in period B is favorable to the accumulation of pollutants from eastern China/Siberia into Alaska and may explain the higher accumulation of $\mathrm{SO}_{2}$ concentrations above Alaska during the TIC-2B-F21 period compared to the TIC-1/2A-F9 period observed from the OMI data (Fig. 6a and c).

The level of acidity of the aerosols forming the TIC-2BF21 ice cloud can also be determined using in situ measurements taken during the ARCPAC/ARCTAS Campaign and by examining the thermodynamic properties of the aerosol layer.

The ARCPAC/ARCTAS projects overlapped in space and time with the Convair 580 aircraft from the ISDAC Campaign. The NASA ARCTAS P-3B and the NOAA ARCPAC WP-3D aircrafts sampled the aerosol acidity near Barrow on 15 April 2008, respectively, between 22:21:00-01:17:00 UTC and 00:25:00-02:12:00 UTC. An aerosol mass spectrometer (AMS) (Dunlea et al., 2009) measuring submicron aerosol mass and composition as a function of their size was used. These data are also within the precision of the ARCPAC AMS measurement (35\%). The observed aerosol 

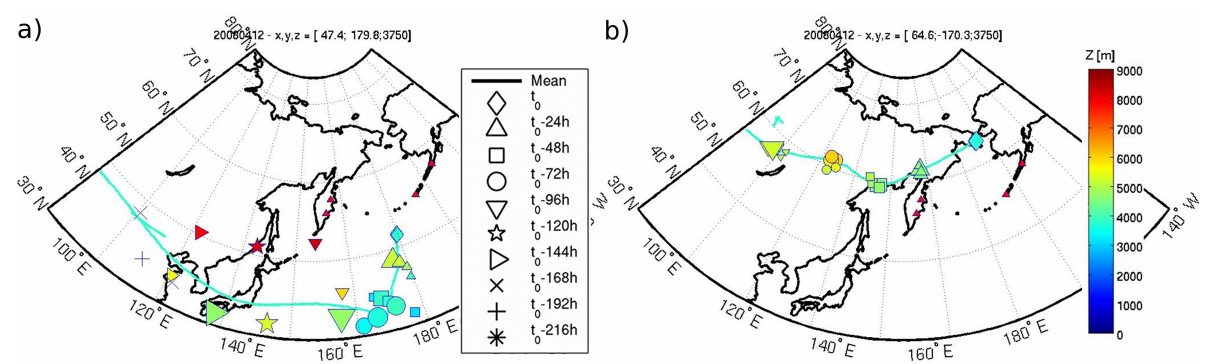

Fig. 14. 10-days backward trajectories from FLEXPART simulations initialized on 12 April 2008 at 14:18:00 UTC for boxes $B_{\mathrm{F} 21} 3$ located at $47.4^{\circ} \mathrm{N}, 179.8^{\circ} \mathrm{W}$ at $3.75 \mathrm{~km}$ in height (a) and $B_{\mathrm{F} 21^{4}} 4$ located at $64.6^{\circ} \mathrm{N},-170.3^{\circ} \mathrm{W}$ at $3.75 \mathrm{~km}$ in height (b). Clusters of particles are represented every $24 \mathrm{~h}$ from the beginning of the simulation. The color bar represents the altitude of cluster in meters. Particles are released during one hour.
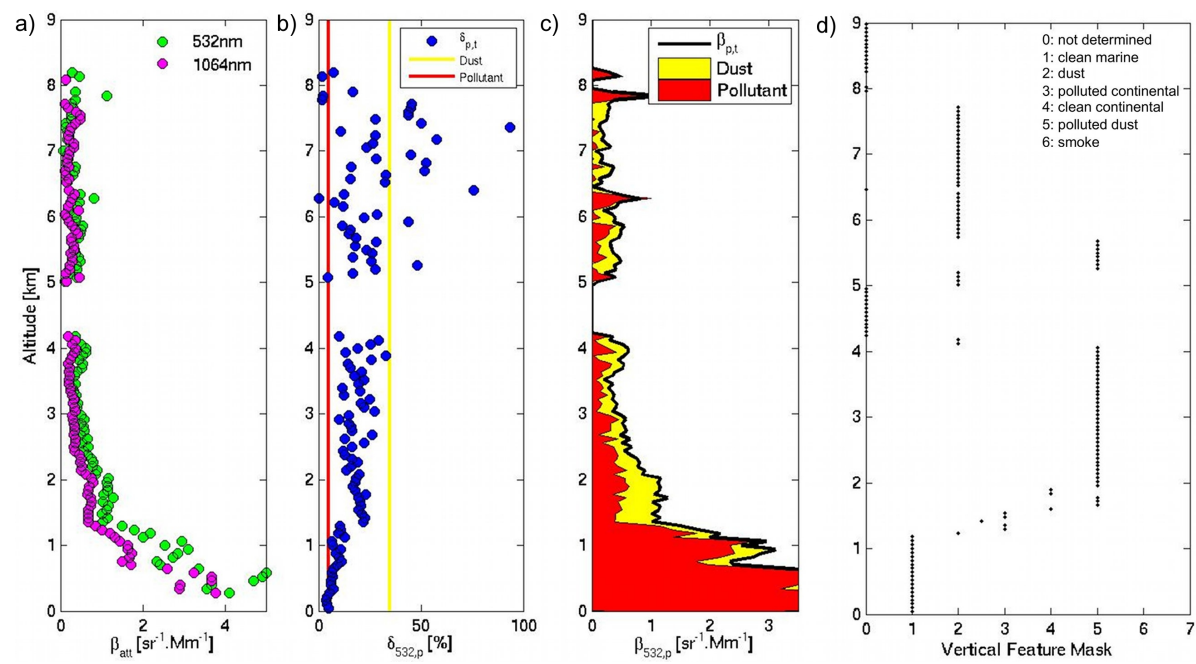

Fig. 15. (a) Total backscatter coefficient at $532 \mathrm{~nm}$ (green) and $1064 \mathrm{~nm}$ (magenta), (b) total particulate depolarization ratio at $532 \mathrm{~nm}$ (green) and the input values of dust (yellow) and anthropogenic (red) particles, (c) separation of dust (yellow) and anthropogenic (red) backscatter coefficients at $532 \mathrm{~nm}$, and (d) vertical feature mask as given by CALIPSO from aerosols layer (ALF21 1) indicated in Fig. 13.

acidity was defined by the mean neutralized fraction as $f=\left(\mathrm{NH}_{4}^{+}\right) /\left(2\left(\mathrm{SO}_{4}^{2-}\right)+\left(\mathrm{NO}_{3}^{-}\right)\right)$with all concentrations in molar units (Fisher et al., 2011). On 15 April 2008, the average observed aerosol acidity in the area $\pm 3^{\circ}$ latitude and longitude coordinates around Barrow and above $2 \mathrm{~km}$ altitude gives low values of the order of $0.33 \pm 0.15$ (P-3B) and $0.46 \pm 0.13$ (WP-3D), indicating the presence of highly acidic aerosols. AMS data from the first two DC-8 ARCTAS flights (1 and 4 April 2008) were excluded due to apparent problems with the instrument (Fisher et al., 2011).

As explained previously, an increase of $\delta_{\mathrm{v}}$ with particulate age during transport can occur as the aerosol loses its coating, exposing the irregular aerosol surface (Sassen et al., 1989). This is possible if an aerosol composed of ammonium sulfate crosses a dry area with a $\mathrm{RH}_{\text {water }}$ below its efflorescence point $(\sim 37 \%)$. However, if the aerosol is coated with a highly acidic compound such as sulfuric acid, which is highly hygroscopic, it will not lose its moisture coating even at very low $\mathrm{RH}_{\text {water }}$. In this situation, $\delta_{\mathrm{v}}$ should remain un- changed. According to the results, aerosol layers $\left(\mathrm{AL}_{\mathrm{F} 21} 2\right.$, $\mathrm{AL}_{\mathrm{F} 21} 3$ and $\mathrm{AL}_{\mathrm{F} 21} 4$ ) forming the TIC-2B are composed of a mixture of dust with anthropogenic and smoke pollutants and $\mathrm{SO}_{2}$. From one aerosol layer to the other, the $\delta_{\mathrm{v}}$ remains unchanged (4-5\%) while $\mathrm{CR}_{\text {att }}$ and $\mathrm{RH}_{\text {water }}$ decrease from 0.31 to 0.24 and 50 to $34.1 \%$, respectively, below the efflorescence point of sulfate ammonium (Table 5). These results support the idea that air masses forming the TIC-2BF21 were composed of acid-coated aerosols. Although no signature of volcanic ash was found in the CALIOP data, the contribution of volcanoes to the $\mathrm{SO}_{2}$ accumulation in Alaska during period $\mathrm{B}$ is a reasonable hypothesis, given the reported volcanic activities by KVERT.

These results seem to be consistent with the initial assumptions according to which the IN activated in the upper part of TIC-1/2A identified in Jouan et al. (2012) would be particles nucleating ice at a $\mathrm{RH}_{\text {Ice }}$ less than $120 \%$, such as mineral dust not covered with an acid and/or organic solution. Also, IN activated in the upper part of TIC-2B identified in Jouan et 
al. (2012) could be particles nucleating ice at a $\mathrm{RH}_{\text {Ice }}$ greater than $120 \%$ at low temperatures $\left(<-30.0^{\circ} \mathrm{C}\right)$, such as acidified mineral dust. The presence of mineral dust in the second case allows us to exclude the role of soot in the cloud formation, since soot is a generally worse ice nucleus than mineral dust.

The overall results of the synoptic situation (Jouan et al., 2012), the in situ characterization of the cloud properties (Jouan et al., 2012), as well as sources, transport of air masses, and analysis of the nature and properties of aerosols upstream the TICs show favorable conditions for the involvement of acidification of aerosols in the formation of the TICs2B-F21. But without representative in situ information on the initial concentration of ice nuclei and chemical composition, we cannot fully validate this hypothesis. This would be one of the topics for further field experiments.

\section{Summary and conclusion}

In this work, the temporal variability of Alaskan averaged $\mathrm{SO}_{2}$ pollution from OMI satellite data, associated with the meteorological conditions during March through April 2008, was presented. Preliminary estimates of the $\mathrm{SO}_{2}$ column amount were calculated based on an assumed $\mathrm{SO}_{2}$ altitude of $5-10 \mathrm{~km}$ above Alaska. Two periods have been distinguished: a relatively clean period (very little $\mathrm{SO}_{2}$ concentration) from 27 March to 3 April 2008, and a more polluted period from 10 to 25 April 2008 with a concentration of $\mathrm{OMI} \mathrm{SO}_{2} 3$ times higher than during the first period. Together with trajectory tools and OMI satellite data, three sources and their transport pathways of $\mathrm{SO}_{2}$ into Alaska were identified during April 2008. The $\mathrm{SO}_{2}$ emitted from northeastern China anthropogenic emissions and from southeastern Siberia biomass burning emissions were generally transported to Alaska, passing over the Kamchatka/Aleutians volcanoes, in 5-7 days throughout the month of April. All of these three identified $\mathrm{SO}_{2}$ pollution sources appear to have a direct influence on the $\mathrm{SO}_{2}$ concentrations streaming into the North Slope of Alaska. The $\mathrm{SO}_{2}$ distributions during the long-range transport were determined primarily by the atmospheric dynamics.

The origin of the air masses in which the ISDAC TIC-1/2A (1 April 2008) and TIC-2B (15 April 2008) were formed was investigated to verify the hypothesis regarding the potential link between acidic aerosols and TIC-2B. Results are discussed by examining the CALIPSO satellite tracks, which intersect the back trajectories in the region away from the airborne measurements. Air masses observed within the upper part of the TIC-1/2A-F9 ice cloud were mainly influenced by a mixture of Asian dust with AE. The separation procedure revealed an aerosol layer ( 2 days before the ISDAC observations) slightly mixed with a higher proportion of pure dust aerosols. Also considering the low volcanic activity of the Kamchatka/Aleutians during this reported period, air masses forming the TIC-1/2A-F9 do not appear acidic. Air masses observed within the upper part of the TIC-2B-F21 ice cloud appear to be mainly influenced by an accumulation (due to specific weather conditions of this two-week later period) of a mixture of Asian dust with BBE and possible VE emissions (due to important daily volcano activity, according to the KVERT report) into Alaska. The separation procedure has revealed aerosol layers ( 3 days before the ISDAC observations) well mixed with a higher proportion of anthropogenic and smoke aerosols. Airborne measurements revealed that aerosols were acidic around Barrow, near the sample ISDAC TIC-2B, on 15 April 2008. The thermodynamic properties associated to the CALIOP volume depolarization ratio also indicate that aerosols were highly acidic during the TIC-2B period.

These results and the analysis of aerosol moistening support the hypothesis that acidic coating on IN could be at the origin of the formation of TIC-2B. However, other studies are needed to confirm this hypothesis, in particular dedicated campaigns to investigate the link between acid-coated aerosols and TIC-2B clouds. Using a model including chemistry and aerosol modules would help to quantify the role of acidified aerosols in the evolution of ice clouds over the Arctic region. This will require quantification of particle sources and inclusion of new interaction processes, which will raise further questions (Fisher et al., 2011). The ice crystal growth rate in very cold conditions impinges on the precipitation efficiency, dehydration and radiation balance. A regional climate model evaluating the impact of the IN deactivation effect by acid coating on the cloud microstructure, precipitation and radiation have also been performed by Girard et al. (2013). Results show that acid coating on dust particles has an important effect on cloud microstructure, atmospheric dehydration, radiation and temperature over the Central Arctic, which is the coldest part of the Arctic.

Acknowledgements. This work was funded by the Natural Sciences and Engineering Research Council of Canada (NSERC), the Fonds Québécois de la Recherche sur la Nature et la Technologie (FQRNT) and the Centre National d'Etudes Spatiales (CNES). A. Stohl (NILU) and ECMWF are acknowledged for providing the FLEXPART model and the meteorological analyses. We also acknowledge the OMI mission scientists and associated NASA personnel for the production of the data used in this research effort. We thank the ICARE Data and Services Center (http://www.icare.univ-lille1.fr/drupal/) for providing access to the space-borne data used in this study. G. Ancellet and R. A. de Villiers are acknowledged for their work on FLEXPART modeling. We thank S. Howell for providing acces to the ARCTAS AMS data.

Edited by: J. Quaas

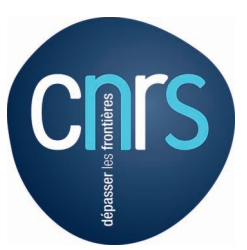

The publication of this article is financed by CNRS-INSU. 


\section{References}

ACIA: Impacts of a warming Arctic: Arctic Climate Impact Assessment, Cambridge University Press, 1042 pp., 2005.

Adams, P. J., Seinfeld, J. H., and Koch, D. M.: Global concentrations of tropospheric sulfate, nitrate, and ammonium aerosol simulated in a general circulation model, J. Geophys. Res., 104, 13791-13823, doi:10.1029/1999JD900083, 1999.

de Villiers, R. A.: Analyse des propriétés optiques des aérosols observés en Arctique pendant la campagne de printemps de l'API/POLARCAT, PhD Thesis, Université Pierre et Marie Curie, 2010.

de Villiers, R. A., Ancellet, G., Pelon, J., Quennehen, B., Schwarzenboeck, A., Gayet, J. F., and Law, K. S.: Airborne measurements of aerosol optical properties related to early spring transport of mid-latitude sources into the Arctic, Atmos. Chem. Phys., 10, 5011-5030, doi:10.5194/acp-10-5011-2010, 2010.

Atkinson, D. E., Sassen, K., Hayashi, M., Cahill, C. F., Shaw, G., Harrigan, D., and Fuelberg, H.: Aerosol properties over Interior Alaska from lidar, DRUM Impactor sampler, and OPCsonde measurements and their meteorological context during ARCTAS-A, April 2008, Atmos. Chem. Phys., 13, 1293-1310, doi:10.5194/acp-13-1293-2013, 2013.

Barrie, L. A. and Barrie M. J.: Chemical Components of Lower Tropospheric Aerosols in the High Arctic: Six Years of Observations, J. Atmos. Chem., 11, 211-226, doi:10.1007/BF00118349, 1990.

Bègue, N., Tulet, P., Chaboureau, J. P., Roberts, G., Gomes, L., and Mallet, M.: Long-range transport of Saharan dust over northwestern Europe during EUCAARI 2008 campaign: Evolution of dust optical properties by scavenging, J. Geophys. Res., 117, D17201, doi:10.1029/2012JD017611, 2012.

Bigg, E. K.: Comparison of aerosol at four baseline atmospheric monitoring stations, J. Appl. Meteorol., 19, 521-533, 1980.

Brock, C. A., Cozic, J., Bahreini, R., Froyd, K. D., Middlebrook, A. M., McComiskey, A., Brioude, J., Cooper, O. R., Stohl, A., Aikin, K. C., de Gouw, J. A., Fahey, D. W., Ferrare, R. A., Gao, R.-S., Gore, W., Holloway, J. S., Hübler, G., Jefferson, A., Lack, D. A., Lance, S., Moore, R. H., Murphy, D. M., Nenes, A., Novelli, P. C., Nowak, J. B., Ogren, J. A., Peischl, J., Pierce, R. B., Pilewskie, P., Quinn, P. K., Ryerson, T. B., Schmidt, K. S., Schwarz, J. P., Sodemann, H., Spackman, J. R., Stark, H., Thomson, D. S., Thornberry, T., Veres, P., Watts, L. A., Warneke, C., and Wollny, A. G.: Characteristics, sources, and transport of aerosols measured in spring 2008 during the aerosol, radiation, and cloud processes affecting Arctic Climate (ARCPAC) Project, Atmos. Chem. Phys., 11, 2423-2453, doi:10.5194/acp-11-24232011, 2011.

Carn, S. A., Krueger, A. J., Krotkov, N. A., Yang, K., and Levelt, P. F.: Sulfur dioxide emissions from Peruvian copper smelters detected by the Ozone Monitoring Instrument, Geophys. Res. Lett., 34, L09801, doi:10.1029/2006GL029020, 2007.

Chernoff, D. I. and Bertram, A. K.: Effects of sulfate coatings on the ice nucleation properties of a biological ice nucleus and several types of minerals, J. Geophys. Res., 115, D20205, doi:10.1029/2010JD014254, 2010.

Chin, M., Rood, R. B., Lin, S.-J., Müller, J.-F., and Thompson, A. M.: Atmospheric sulfur cycle simulated in the global model GOCART: Model description and global properties, J. Geophys. Res., 105, 24671-24687, 2000.
Delanoë, J., and Hogan, R.J.: A variational scheme for retrieving ice cloud properties from combined radar, lidar and infrared radiometer, J. Geophys. Res., 113, D07204, doi:10.1029/2007JD009000, 2008.

Delanoë, J. and Hogan, R. J.: Combined CloudSat-CALIPSOMODIS retrievals of the properties of ice clouds, J. Geophys. Res., 115, D00H29, doi:10.1029/2009JD012346, 2010.

Devasthale, A., Tjernström, M., Karlsson, K. G., Thomas, M. A., Jones, C., Sedlar, J., and Omar, A. H.: The vertical distribution of thin features over the Arctic analysed from CALIPSO observations - Part I: Optically thin clouds, Tellus, 63, 77-85, doi:10.1111/j.1600-0889.2010.00516.x, 2011.

Dufresne, J.-L. and Bony, S.: An assessment of the primary sources of spread of global warming estimates from coupled atmosphere-ocean models, J. Climate, 21, 5135-5144, doi:10.1175/2008JCLI2239.1, 2008.

Dunlea, E. J., DeCarlo, P. F., Aiken, A. C., Kimmel, J. R., Peltier, R. E., Weber, R. J., Tomlinson, J., Collins, D. R., Shinozuka, Y., McNaughton, C. S., Howell, S. G., Clarke, A. D., Emmons, L. K., Apel, E. C., Pfister, G. G., van Donkelaar, A., Martin, R. V., Millet, D. B., Heald, C. L., and Jimenez, J. L.: Evolution of Asian aerosols during transpacific transport in INTEX-B, Atmos. Chem. Phys., 9, 7257-7287, doi:10.5194/acp-9-7257-2009, 2009.

Eastwood, M. L., Cremel, S., Wheeler, M., Murray, B. J., Girard, E., and Bertram, A. K.: Effects of sulfuric acid and ammonium sulfate coatings on the ice nucleation properties of kaolinite particles. Geophys. Res. Lett., 36, L02811, doi:10.1029/2008GL035997, 2009.

Eguchi, K., Uno, I., Yumimoto, K., Takemura, T., Shimizu, A., Sugimoto, N., and Liu, Z.: Trans-pacific dust transport: integrated analysis of NASA/CALIPSO and a global aerosol transport model, Atmos. Chem. Phys., 9, 3137-3145, doi:10.5194/acp-93137-2009, 2009.

Fisher, J. A., Jacoba, D. J., Wanga, Q., Bahreinib, R., Carougea, C. C., Cubisonb, M. J., Dibbe, J. E., Diehlf, T., Jimenezb, J.L., Leibenspergera, E. M., Meindersh, M. B. J., Pyei, H. O. T., Quinnj, P. K., Sharmak, S., Van Donkelaarl, A., and Yantoscaa, R. M.: Sources, distribution, and acidity of sulfate-ammonium aerosol in the Arctic in winter-spring, Atmos. Environ., 45, 7301-7318, doi:10.1016/j.atmosenv.2011.08.030, 2011.

Giannakaki, E., Balis, D., and Amiridis, V.: Vertical Separation of Aerosol Types Using of CALIPSO Level-2 Products. Springer Atmospheric Sciences. Part 3, 981-986, doi:10.1007/978-3-64229172-2_137, 2012.

Girard, E. and Blanchet, J. P.: Simulation of Arctic diamond dust and ice fog or thin stratus using an explicit aerosolcloud-radiation model, J. Atmos. Sci., 58, 1199-1221, doi:10.1175/1520-0469(2001)058<1199:SOADDI>2.0.CO;2, 2001.

Girard, E., Dueymes, G., Du, P., and Bertram, A. K.: Assessment of the Effects of Acid-Coated Ice Nuclei on the Arctic Cloud Microstructure, Atmospheric Dehydration, Radiation and Temperature during Winter, Int. J. Climatol., 33, 599-614, doi:10.1002/joc.3454, 2013.

Grenier, P. and Blanchet, J. P: Investigation of the sulphateinduced freezing inhibition effect from CloudSat and CALIPSO measurements, J. Geophys. Res., 115, D22205, doi:10.1029/2010JD013905, 2010. 
Grenier, P., Blanchet, J. P., and Munoz-Alpizar, R.: Study of polar thin ice clouds and aerosols seen by CloudSat and CALIPSO during mid-winter 2007, J. Geophys. Res., 114, D09201, doi:10.1029/2008JD010927, 2009.

Harrigan, D. L., Fuelberg, H. E., Simpson, I. J., Blake, D. R., Carmichael, G. R., and Diskin, G. S.: Anthropogenic emissions during Arctas-A: mean transport characteristics and regional case studies, Atmos. Chem. Phys., 11, 8677-8701, doi:10.5194/acp11-8677-2011, 2011.

He, H., Li, C., Loughner, C. P., Li, Z., Krotkov, N. A., Yang, K., Wang, L., Zheng, Y., Bao, X., Zhao, G., and Dickerson, R. $\mathrm{R}$.: $\mathrm{SO}_{2}$ over central China: Measurements, numerical simulations and the tropospheric sulfur budget, J. Geophys. Res., 117, D00K37, doi:10.1029/2011JD016473, 2012.

Hirdman, D., Burkhart, J. F., Sodemann, H., Eckhardt, S., Jefferson, A., Quinn, P. K., Sharma, S., Ström, J., and Stohl, A.: Longterm trends of black carbon and sulphate aerosol in the Arctic: changes in atmospheric transport and source region emissions, Atmos. Chem. Phys., 10, 9351-9368, doi:10.5194/acp-10-93512010, 2010.

Hoose, C. and Möhler, O.: Heterogeneous ice nucleation on atmospheric aerosols: a review of results from laboratory experiments, Atmos. Chem. Phys., 12, 9817-9854, doi:10.5194/acp-12-98172012, 2012.

Intrieri, J. M. and Shupe, M. D.: Characterization and radiative effects of diamond dust of the Western Arctic Ocean region, J. Climate, 17, 2953-2960, 2004.

IPCC: Climate Change 2007: Intergovernmental Panel of Climate Change, The Physical Science Basis, Cambridge University Press, 996 pp., 2007.

Jacob, D. J., Crawford, J. H., Maring, H., Clarke, A. D., Dibb, J. E., Emmons, L. K., Ferrare, R. A., Hostetler, C. A., Russell, P. B., Singh, H. B., Thompson, A. M., Shaw, G. E., McCauley, E., Pederson, J. R., and Fisher, J. A.: The Arctic Research of the Composition of the Troposphere from Aircraft and Satellites (ARCTAS) mission: design, execution, and first results, Atmos. Chem. Phys., 10, 5191-5212, doi:10.5194/acp-10-5191-2010, 2010.

Jouan, C., Girard, E., Pelon, J., Gultepe, I., Delanoë, J., and Blanchet, J. P.: Characterization of Arctic ice cloud properties observed during ISDAC, J. Geophys. Res., 117, D23207, doi:10.1029/2012JD017889, 2012.

Krotkov, N. A., Carn, S. A., Krueger, A. J., Bhartia, P. K., and Yang, $\mathrm{K}$.: Band residual difference algorithm for retrieval of $\mathrm{SO}_{2}$ from the Aura Ozone Monitoring Instrument (OMI), IEEE T. Geosci. Remote, 44, 1259-1266, doi:10.1109/TGRS.2005.861932, 2006.

Krotkov, N. A., McClure, B., Dickerson, R. R., Carn, S. A., Li, C., Bhartia, P. K., Yang, K., Krueger, A. J., Li, Z., Levelt, P. F., Chen, $\mathrm{H}$., Wang, P., and $\mathrm{Lu}, \mathrm{D}$.: Validation of $\mathrm{SO}_{2}$ retrievals from the Ozone Monitoring Instrument over NE China, J. Geophys. Res., 113, D16S40, doi:10.1029/2007JD008818, 2008.

Lampert, A., Ehrlich, A., Dörnbrack, A., Jourdan, O., Gayet, J.F., Mioche, G., Shcherbakov, V., Ritter, C., and Wendisch, M.: Microphysical and radiative characterization of a subvisible midlevel Arctic ice cloud by airborne observations - a case study, Atmos. Chem. Phys., 9, 2647-2661, doi:10.5194/acp-9-26472009, 2009.

Law, K. S. and Stohl, A.: Arctic air pollution: Origins and impacts, Science, 315, 1537-1540, doi:10.1126/science.1137695, 2007.
Lee, C., Martin, R. V., van Donkelaar, A., O’Byrne, G., Krotkov, N., Richter, A., Huey, L. G., and Holloway, J. S.: Retrieval of vertical columns of sulfur dioxide from SCIAMACHY and OMI: Air mass factor algorithm development, validation, and error analysis, J. Geophys. Res., 114, D22303, doi:10.1029/2009JD012123, 2009.

Liu, Z., Vaughan, M., Winker, D., Kittaka, C., Getzewich, B., Kuehn, R., Omar, A., Powell, K., Trepte, C., and Hostetlerd, C.: The CALIPSO Lidar Cloud and Aerosol Discrimination: Version 2 Algorithm and Initial Assessment of Performance, J. Atmos. Ocean. Tech., 26, 1198-1213, doi:10.1175/2009JTECHA1229.1, 2009.

Lopez, T., Carn, S., Werner, C., Fee, D., Kelly, P., Doukas, M., Pfeffer, M., Webley, P., Cahill, C., and Schneider, D.: Evaluation of Redoubt Volcano's Sulfur Dioxide Emissions by the Ozone Monitoring Instrument, J. Volcanol. Geoth. Res., 259, 290-307, doi:10.1016/j.jvolgeores.2012.03.002, 2012.

Lu, Z., Streets, D. G., Zhang, Q., Wang, S., Carmichael, G. R., Cheng, Y. F., Wei, C., Chin, M., Diehl, T., and Tan, Q.: Sulfur dioxide emissions in China and sulfur trends in East Asia since 2000, Atmos. Chem. Phys., 10, 6311-6331, doi:10.5194/acp-106311-2010, 2010.

McFarquhar, G. M., Ghan, S., Verlinde, J., Korolev, A., Strapp, J. W., Schmid, B., Tomlinson, J., Brooks, S. D., Collins, D. R., Cziczo, D., Dubey, M. K., Gultepe, I., Kok, G., Laskin, A., Lawson, P., Liu, P., Lubin, D., Mazzoleni, C., MacDonald, A. M., Wolde, M., Zelenyuk, A., Ferrare, R. A., Flynn, C., Shupe, M., Turner, D. D., Ovtchinnikov, M., Xie, S., and Liu, X.: Indirect and Semi-direct Aerosol Campaign. The Impact of Arctic Aerosols on Clouds, B. Am. Meteorol. Soc., 92, 183-201, doi:10.1175/2010BAMS2935.1, 2011.

Mishchenko, M. I. and Sassen, K.: Depolarization of lidar returns by small ice crystals: An application to contrails, Geophys. Res. Lett., 25, 309-312, 1998.

Morrison, H., Curry, K. D., Shupe, M. D., and Zuidema, P.: A New Double-Moment Microphysics Parameterization for Application in Cloud and Climate Models. Part II: Single-Column Modeling of Arctic Clouds, J. Atmos. Sci., 62, 1678-1693, doi:10.1175/JAS3447.1, 2005.

Morrison, H., de Boer, G., Feingold, G., Harrington, J., Shupe M. D., and Sulia, K.: Resilience of persistent Arctic mixed-phase clouds, Nat. Geosci., 5, 11-17, doi:10.1038/NGEO1332, 2012.

Prenni, A. J., Demott, P. J., Rogers, D. C., Kreidenweis, S. M., McFarquhar, G. M., Zhang, G., and Poellot, M. R.: Ice nuclei characteristics from M-PACE and their relation to ice formation in clouds, Nat. Geosci., 2, 402-405, 2009.

Quinn, P. K., Shaw, G., Andrews, E., Dutton, E. G., RuohoAirola, T., and Gong, S. L.: Arctic haze: current trends and knowledge gaps, Tellus, 59, 99-114, doi:10.1111/j.16000889.2006.00238.x, 2007.

Sassen, K., Zhao, H., and Yu, B. K.: Backscatter laser depolarization studies of simulated stratospheric aerosols: Crystallized sulfuric acid droplets, Appl. Optics, 28, 3024-3029, 1989.

Seinfeld, J. H. and Pandis, S. N.: Atmospheric Chemistry and Physics: From Pollution to Climate Change, John Wiley \& Sons, Inc., New York, 1232 pp., 1998.

Shimizu, A., Sugimoto, N., Matsui, I., Arao, K., Uno, I., Murayama, T., Kagawa, N., Aoki, K., Uchiyama, A., and Yamazaki, A.: Continuous observations of Asian dust and other aerosols by 
polarization lidars in China and Japan during ACE-Asia, J. Geophys. Res., 109, D19S17, doi:10.1029/2002JD003253, 2004.

Shupe, M. D.: Clouds at Arctic Atmospheric Observatories, Part II: Thermodynamic phase characteristics, J. Appl. Meteorol. Clim., 50, 645-661, doi:10.1175/2010JAMC2468.1, 2011.

Shupe, M. D. and Intrieri, J. M.: Cloud radiative forcing of the Arctic surface: The influence of cloud properties, surface albedo, and solar zenith angle, J. Climate, 17, 616-628, doi:10.1175/15200442(2004)017<0616:CRFOTA>2.0.CO;2, 2004.

Spinei, E., Carn, S. A., Krotkov, N. A., Mount, G. H., Yang, K., and Krueger, A.: Validation of ozone monitoring instrument $\mathrm{SO}_{2}$ measurements in the Okmok volcanic cloud over Pullman, WA, July 2008, J. Geophys. Res., 115, D00L08, doi:10.1029/2009JD013492, 2010.

Stohl, A., Hittenberger, M., and Wotawa, G.: Validation of the Lagrangian particle dispersion model FLEXPART against large scale tracer experiment data, Atmos. Environ., 32, 4245-4264, 1998.

Stohl, A., Eckhardt, S., Forster, C., James, P., Spichtinger, N., and Seibert, P.: A replacement for simple back trajectory calculations in the interpretation of atmospheric trace substance measurements, Atmos. Environ., 36, 4635-4648, 2002.

Sugimoto, N., Uno, I., Nishikawa, M., Shimizu, A., Matsui, I., Dong, X., Chen, Y., and Quan, H.: Record heavy Asian dust in Beijing in 2002: Observations and model analysis of recent events, Geophys. Res. Lett., 30, 1640, doi:10.1029/2002GL016349, 2003.

Sullivan, R. C., Petters, M. D., DeMott, P. J., Kreidenweis, S. M., Wex, H., Niedermeier, D., Hartmann, S., Clauss, T., Stratmann, F., Reitz, P., Schneider, J., and Sierau, B.: Irreversible loss of ice nucleation active sites in mineral dust particles caused by sulphuric acid condensation, Atmos. Chem. Phys., 10, 1147111487, doi:10.5194/acp-10-11471-2010, 2010.

Tesche, M., Ansmann, A., Müller, D., Althausen, D., Engelmann, R., Freudenthaler, V., and Groß, S.: Vertically resolved separation of dust and smoke over Cape Verde using multiwavelength Raman and polarization lidars during Saharan Mineral Dust Experiment 2008, J. Geophys. Res., 114, D13202, doi:10.1029/2009JD011862, 2009.

Tu, F. H., Thornton, D. C., Bandy, A. R., Carmichael, G. R., Tang, Y., Thornhill, K. L., Sachse, G. W., and Blake, D. R.: Long-range transport of sulfur dioxide in the central Pacific, J. Geophys. Res., 109, D15S08, doi:10.1029/2003JD004309, 2004.
Uno, I., Eguchi, K., Yumimoto, K., Takemura, T., Shimizu, A., Uematsu, M., Liu, Z., Wang, Z., Hara, Y., and Sugimoto, N.: Asian dust transported one full circle around the globe, Nat. Geosci., 2, 557-560, doi:10.1038/NGEO583, 2009.

Usher, C. R., Michel, A. E., and Grassian, V. H.: Reactions on mineral dust, Chem. Rev., 103, 4883-4939, 2003.

Uttal, T., Curry, J. A., McPhee, M. G., Perovich, D. K., Moritz, R. E., Maslanik, J. A., Guest, P. S., Stern, H. L., Moore, J. A., Turenne, R., Heiberg, A., Serreze, M. C., Wylie, D. P., Persson, P. O. G., Paulson, C. A., Halle, C., Morison, J. H., Wheeler, P. A., Makshtas, A., Welch, H., Shupe, M. D., Intrieri, J. M., Stamnes, K., Lindsey, R. W., Pinkel, R., Pegau, W. S., Stanton, T. P., and Grenfeld, T. C.: Surface Heat Budget of the Arctic Ocean, B. Ame. Meteorol. Soc., 83, 255-275, doi:10.1175/15200477(2002)083<0255:SHBOTA>2.3.CO;2, 2002.

Warneke, C., Bahreini, R., Brioude, J., Brock, C. A., De Gouw, J. A., Fahey, D. W., Froyd, K. D., Holloway, J. S., Middlebrook, A., Miller, L., Montzka, S., Murphy, D. M., Peischl, J., Ryerson, T. B., Schwarz, J. P., Spackman, J. R., and Veres, P.: Biomass burning in Siberia and Kazakhstan as the main source for Arctic Haze over the Alaskan Arctic in April 2008, Geophys. Res. Lett. 36, L02813, doi:10.1029/2008GL036194, 2009.

Warneke, C., Froyd, K. D., Brioude, J., Bahreini, R., Brock, C. A., Cozic, A., de Gouw, J. A., Fahey, D. W., Ferrare, R. A., Holloway, J. S., Middlebrook, A. M., Miller, L., Montzka, S., Schwarz, J. P., Sodemann, H., Spackman, J. R., and Stohl, A.: An important contribution to springtime Arctic aerosol from biomass burning in Russia, Geophys. Res. Lett., 37, L01801, doi:10.1029/2009GL041816, 2010.

Yalcin, K., Wake, C. P., and Germani, M.: A 100-year record of North Pacific volcanism in an ice core from Eclipse Icefield, Yukon Territory, Canada, J. Geophys. Res., 108, 4012, doi:10.1029/2002JD002449, 2002.

Yang, K., Krotkov, N. A., Krueger, A. J., Carn, S. A., Bhartia, P. K., and Levelt, P. F.: Retrieval of large volcanic $\mathrm{SO}_{2}$ columns from the Aura Ozone Monitoring Instrument: Comparison and limitations, J. Geophys. Res., 112, D24S43, doi:10.1029/2007JD008825, 2007.

Zelenyuk, A., Imre, D., Earle, M., Easter, R., Korolev, A., Leaitch, R., Liu, P., Mac-donald, A. M., Ovchinnikov, M., and Strapp, W. In Situ Characterization of Cloud Condensation Nuclei, Interstitial, and Background Particles Using the Single Particle Mass Spectrometer, SPLAT II, Anal. Chem. 82, 7943-7951, 2010. 